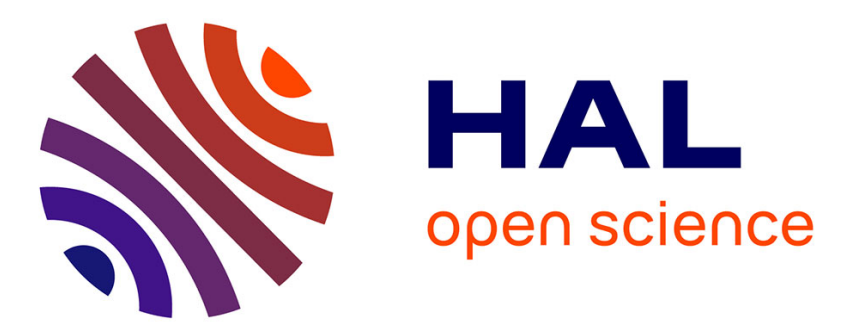

\title{
Original Fluorinated Copolymers Achieved by Both Azide/Alkyne "Click" Reaction and Hay Coupling from Tetrafluoroethylene Telomers
}

\author{
Aurelien Soules, Bruno Ameduri, Bernard Boutevin, Gérard Calleja
}

\section{- To cite this version:}

Aurelien Soules, Bruno Ameduri, Bernard Boutevin, Gérard Calleja. Original Fluorinated Copolymers Achieved by Both Azide/Alkyne "Click" Reaction and Hay Coupling from Tetrafluoroethylene Telomers. Macromolecules, 2010, 43, pp.4489-4499. 10.1021/ma100634q · hal-00477621

\author{
HAL Id: hal-00477621 \\ https://hal.science/hal-00477621
}

Submitted on 29 Apr 2010

HAL is a multi-disciplinary open access archive for the deposit and dissemination of scientific research documents, whether they are published or not. The documents may come from teaching and research institutions in France or abroad, or from public or private research centers.
L'archive ouverte pluridisciplinaire HAL, est destinée au dépôt et à la diffusion de documents scientifiques de niveau recherche, publiés ou non, émanant des établissements d'enseignement et de recherche français ou étrangers, des laboratoires publics ou privés. 


\title{
Original Fluorinated Copolymers Achieved by both
}

\author{
Azide/Alkyne \\ "Click" Reaction and Hay Coupling from \\ Tetrafluoroethylene Telomers
}

Aurélien Soules, Bruno Ameduri*, Bernard Boutevin, Gerard Calleja

Ingénierie et Architectures Macromoléculaires, Institut Charles Gerhardt, UMR 5253 CNRS

ENSCM UMI UMII, Ecole Nationale Supérieure de Chimie de Montpellier, 8 rue de 1Ecole Normale, 34296 Montpellier Cedex 05, France

Authors email addresses : aurelien.soules@enscm.fr; bruno.ameduri@enscm.fr; bernard.boutevin@enscm.fr; gerard.calleja@enscm.fr

RECEIVED DATE (to be automatically inserted after the manuscript is accepted if required according to the journal that you are submitting your paper to) TITLE RUNNING HEAD: “Click” Reaction and Hay Coupling from Tetrafluoroethylene Telomers 
ABSTRACT. The synthesis and characterization of an original class of linear poly(alkylaryl) ethers containing 1,2,3-triazolyl and fluorinated moieties based on oligo(tetrafluoroethylene) telomer are presented. These polymers were prepared, from $\alpha, \omega-$ dipropargyl ether bisphenol $\mathrm{AF}$ and 1,10-diazido-1H,1H,2H,2H,9H,9H,10H,10Hperfluorodecane, in $62 \%$ overall yields, via the azide/alkyne "Click" reaction and/or oxidative coupling of acetylenes (Hay reaction). The latter reactant was produced from the ethylene end-capping of oligo(tetrafluoroethylene) followed by a nucleophilic substitution with sodium azide. A simple tuning of the reaction conditions allowed us to direct the originally favored "Click" reaction towards a competitive homocoupling of the terminal alkynes, thus leading to copolymers with drastically different structures, as evidenced by size exclusion chromatography, DSC RAMAN and UV-vis spectroscopy. Hence, original poly(alkyl aryl) ether copolymers with a high thermal stability (higher than $300{ }^{\circ} \mathrm{C}$ ) that exhibit alternating statistic or block microstructures were obtained.

KEYWORDS: Click Chemistry; Hay Coulping; Fluoropolymers; RAMAN and NMR Spectrocopies; Thermal Properties 


\section{INTRODUCTION.}

Over the past decades, fluoropolymers have been attractive in the development of advanced materials endowed with high thermal and oxidative stabilities, chemical inertness and superior electrical insulating ability for high tech applications such as thin film coatings, cladding for optical fibers, membranes for fuel cells, separators for lithium ion batteries. ${ }^{1-3}$ Meanwhile, efforts have been made to develop thermally curable materials based on propargyl methacrylate ${ }^{4}$ and linear polymers of propargyl derivatives of bisphenol. ${ }^{5-7}$ Dipropargyl ether of bisphenol A and its B-staged materials have been attractive substitutes for epoxy resins involved in advanced composites, adhesives, coatings and for electronics applications. ${ }^{8-10}$ In fact, the obtained resins exhibit thermoset characteristics, excellent thermal stability (around $\left.350{ }^{\circ} \mathrm{C}\right)$, low dielectric constants ( $\left.\mathrm{ca} .2 .77\right)$ and are highly hydrophobic matrices.

Furthermore, it is known that terminal acetylenes that have propargyl groups are able to undergo an oxidative homocoupling. ${ }^{11}$ One of the main methods to obtain oligo- or polyacetylene consists in achieving such homocoupling via Hay's protocole ${ }^{12 \mathrm{a}-\mathrm{b}}$ (Scheme 1).

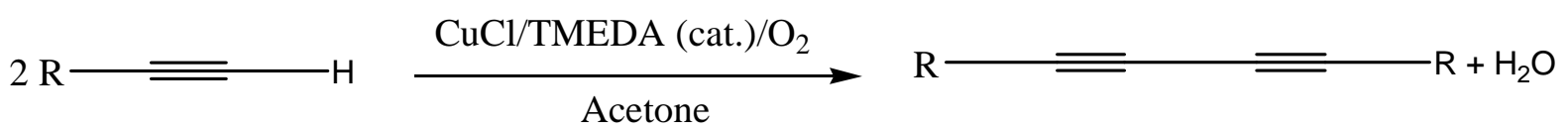

Scheme 1: Hay homocoupling of $\omega$-acetylenic derivatives (where TMEDA stands for $\mathrm{N}, \mathrm{N}, \mathrm{N}, \mathrm{N}$ '-tetramethylethylene diamine).

This coupling is based on dimerization through oxidation of copper (I) acetylides species by copper (II). The use of aminated bidendate ligands such as N,N,N,N'-tetramethylethylene diamine $^{11 \mathrm{~b}}$ (TMEDA) or 2,2'-bipyridine ${ }^{13}$ (bpy) enables the formation of copper (I) acetylide species. On the other hand, the ligand creates a bridge between copper (I) and copper (II) that 
favors electron transfer and thus increases the kinetics of the coupling. Indeed, acetylenic coupling is currently a powerful tool in molecular ${ }^{14}$ and macromolecular designs. ${ }^{15}$

Acetylenic groups have also been involved in various reactions, and recently Sharpless' group ${ }^{16}$ has popularized the azide/alkyne "Click" reaction. This reaction is a variation of the Huisgen 1,3-dipolar cycloaddition reaction between terminal acetylenes and azides catalyzed by an organometallic complex. Different mechanisms of this reaction have been proposed. A recent one was suggested by Bock et $a l^{17}$ who reported that "Click" reaction is a multistep 1,4 regio specific reaction involving the formation of complexes of copper (I) acetylide. The kinetics of this reaction ${ }^{18-20}$ have shown that it was of second order with respect to the copper concentration when the metal is used in catalytic amounts. Usual catalytic systems are aromatic and aliphatic aminated ligands. ${ }^{21-25}$

This methodology has been successfully applied in organic chemistry, ${ }^{26-27}$ supramolecular chemistry $^{28-30}$ and materials Science, ${ }^{31-32}$ leading to interesting materials: dendronized polymers, ${ }^{31-34}$ conjugated polymers, ${ }^{35}$ or incorporation of 1,2,3-triazole ring into polymers by grafting. ${ }^{36-42}$ Only a few groups have studied the incorporation of 1,2,3-triazole ring into the backbone of linear polymers by polycondensation. ${ }^{43-51}$

When the respective mechanisms of Hay coupling and "Click" reaction are compared, it appears that in a system where both end-groups are present, the course of the reaction depends on various experimental conditions: (i) the presence or lack of oxygen, (ii) the copper (II) salt concentration, and (iii) the nature of the copper ligand. Under regular "Click" reaction conditions (traces of oxygen, addition of an appropriate reducing agent and aliphatic aminated ligand, such as $\mathrm{N}, \mathrm{N}, \mathrm{N}$ ',N",N"-pentamethyldiethylenetriamine, the "Click" reaction is much faster than Hay coupling and the latter is generally not observed.

Recently, Cummins et al. ${ }^{52 a}$ have reported that in the course of the grafting of polystyrene chains bearing alkyne functions by "Click" reaction onto a surface bearing azide groups, the 
coupling of these chains via the formation of diacetylenic segments occurred. Since then, homocoupling (according to Hay's protocol) of the alkyne extremities of a macromolecular polystyrene synthesized by ATRP has been further confirmed by the same group. ${ }^{52 \mathrm{~b}}$

This work intends to bring some new insights in the still scarce examples of competitive Hay coupling and "Click" reaction provided by the literature. The synthesis and characterization of an original class of linear poly(alkyl-aryl) ethers containing 1,2,3-triazolyl and fluorinated moieties [based on oligo(tetrafluoroethylene) telomers] is reported. By subtle changes in the reaction conditions, the copolymerization between a fluorinated telechelic telomer bearing azido functions and a propargylic oligomer containing terminal alkynes could be controlled from classic azide/alkyne "Click" addition towards the promotion of a competitive homocoupling of the alkyne end groups, thus leading to either alternated or block copolymers bearing different functional groups.

\section{EXPERIMENTAL}

Reactants. Di-(4-tert-butylcyclohexyl)peroxydicarbonate used as the intiator was kindly supplied from Akzo Nobel. Dimethylsulfoxide (DMSO), tetrahydrofuran (THF), diethyl ether (from Aldrich) and tert-butanol (Acros Organics, 98\%) were distilled prior to use. 1,6Diiodoperfluorohexane was purchased from Daikin. Copper (I) bromide (Acros Organics, 95\%) was washed with glacial acetic acid to remove any soluble oxidized species and then filtered, washed with ethanol, and dried. Hexafluoro bisphenol AF, propargyl bromide, sodium azide, $\mathrm{Na}_{2} \mathrm{SO}_{4}$ and 2,2'-bipyridine (bpy) were purchased from Aldrich.

Analyses and characterizations. ${ }^{1} \mathrm{H},{ }^{13} \mathrm{C}$ and ${ }^{19} \mathrm{~F}$ NMR spectra were recorded on a Brüker $400 \mathrm{MHz}$ FT NMR spectrometer with either deuterated chloroform or acetone as solvents. Chemical shifts are reported in ppm relative to tetramethylsilane (TMS) for ${ }^{1} \mathrm{H},{ }^{13} \mathrm{C}$ spectra 
and to $\mathrm{CFCl}_{3}$ for ${ }^{19} \mathrm{~F}$ NMR spectra. Letters $\mathrm{s}, \mathrm{d}, \mathrm{t}$, q stand for singlet, doublet, triplet and quintet, and the coupling constants are in Hz. Fourrier transformed IR spectra were performed on a Nicolet 510P Fourrier spectrometer with an accuracy of $\pm 2 \mathrm{~cm}^{-1}$ using OMNIC® software.

The relative viscosity measurements were achieved in a thermostated bath at $35{ }^{\circ} \mathrm{C}$, using a Ubbelohde viscosimeter Ref. No. 50110 equipped with a capillary with an inner diameter of $0.53 \mathrm{~mm}$. Determination of intrinsic viscosity was based on four reduced viscosity measurements at concentrations ranging from 0.1 to $0.5 \mathrm{~g}$ per $100 \mathrm{~mL}$ of acetone.

Size exclusion chromatography was carried out in DMF with a flow rate of $0.8 \mathrm{~mL} \cdot \mathrm{min}^{-1}$ and a PL gel Mix column at $30{ }^{\circ} \mathrm{C}$. Detection was performed using a RI spectra physic detector SP8430. Analyses were achieved by injection of $20 \mu \mathrm{L}$ of the polymer solution $\left(5 \mathrm{mg} \cdot \mathrm{mL}^{-1}\right)$ in DMF (polymer dissolved readily in DMF leading to a clear solution). The molecular weights and polydispersity indices were assessed using the Waters Breeze ${ }^{\circledR}$ software package. The system was calibrated by using commercially available monodispersed poly(styrene) standards from Polymer Laboratories.

The Raman spectra, were recorded on a Labram Aramis Horiba Jobin Yvon with $\mathrm{IR}^{2}$ option (Excitation wave length $633.5 \mathrm{~nm}$ ). The microscope lens was a LWD Olympus (X50). The spectral resolution was $1.6 \mathrm{~cm}^{-1}$.

The study of the thermal cross-linking of polymer (4) was performed by means of a Perkin Elmer-UV20 spectrometer with a scan speed of $480 \mathrm{~nm}$ per minute. Polymer (4) was dissolved in THF ( $2 \mathrm{mg} / \mathrm{mL})$ andthe solution was spread on a quartz substrate and then spin coated on a Karl Suss Technique SA apparatus (CT60 model) (acceleration of $1000 \mathrm{rpm}$, a spinning speed of $1500 \mathrm{rpm}$ for $30 \mathrm{~s})$ to produce thin films ( 1 $\mu \mathrm{m}$ thick) for the UV analysis. Differential scanning calorimetry (DSC) analyses were carried out with a Perkin Elmer Pyris 1 DSC apparatus under nitrogen atmosphere at a heating rate of $20^{\circ} \mathrm{C} / \mathrm{min}$. DSC system was 
first calibrated in temperature using indium and n-hexane. The sample was heated from -150 to $220{ }^{\circ} \mathrm{C}$, followed by a cooling step and then a heating step again. The second runs led to the Tg values assessed from the inflexion point in the heat capacity jump.

Thermogravimetric analyses were performed under air and nitrogen on a TGA Q50 apparatus from TA Instruments at a heating rate of $20^{\circ} \mathrm{C} / \mathrm{min}$.

Synthesis of a, $\omega$-dipropargyl ether bisphenol AF (A). To a flame dried $250 \mathrm{~mL}$ three-neck round-bottom flask were added propargyl bromide (10.05 g, $53.7 \mathrm{mmol})$, bisphenol AF (compound 2) (12.80 g, $107.4 \mathrm{mmol})$ and anhydrous potassium hydroxyde (20.70 g, 150 mmol). The flask was flushed with nitrogen and then dried acetone $(20 \mathrm{~mL})$ was added via a syringe. The mixture was stirred at room temperature for $12 \mathrm{hrs}$. The resulting solution was poured into diethyl ether $(20 \mathrm{~mL})$. The crude product was recrystallized twice from methanol to give a light yellow powder (11.13 g) (Yield=50\%). FT IR ( $\mathrm{KBr}$,

$\left.\mathrm{cm}^{-1}\right): 2280\left(v_{\mathrm{C} \equiv \mathrm{C}-\mathrm{H}}\right), 1000-1200\left(v_{\mathrm{C}-\mathrm{F}}\right)$. RAMAN shift $\left(\mathrm{cm}^{-1}\right): 904\left(v_{\mathrm{C}-\mathrm{F}}\right), 1000-1200\left(v_{\text {aromatic C}}\right.$ $\mathrm{H}$ in-plane bend $), 1480\left(v_{\mathrm{C}-\mathrm{O}}\right), 1600$ ( $\left.v_{\text {ring stretch }}\right), 2133 \mathrm{~cm}^{-1}\left(v_{\mathrm{C}=\mathrm{C}}\right) .{ }^{1} \mathrm{H} \mathrm{NMR}\left(400 \mathrm{MHz} ; \mathrm{d}_{6}\right.$-acetone): $\delta(\mathrm{ppm}) 3.1\left(2 \mathrm{H}, \mathrm{t},{ }^{4} J_{\mathrm{HH}}=2.4 \mathrm{~Hz}\right), 4.8\left(4 \mathrm{H}, \mathrm{d},{ }^{4} J_{\mathrm{HH}}=2.3 \mathrm{~Hz}\right), 6.8\left(4 \mathrm{H}, \mathrm{d},{ }^{3} J_{\mathrm{HH}}=8.55 \mathrm{~Hz}\right)$, $7.4\left(4 \mathrm{H}, \mathrm{d},{ }^{3} J_{\mathrm{HH}}=8.55 \mathrm{~Hz}\right) .{ }^{19} \mathrm{~F}$ NMR $\left(400 \mathrm{MHz} ; \mathrm{d}_{6}\right.$-acetone $): \delta(\mathrm{ppm})-63.2(6 \mathrm{~F}, \mathrm{~m}) .{ }^{13} \mathrm{C}$ NMR (400 MHz; $\mathrm{d}_{6}$-acetone): $\delta$ (ppm) 158.8, 132.2, 126.7, 115.4, 100.4, 78.6, 75.4, 56.7.

Synthesis of 1,10-diiodo-1H,1H,2H,2H,9H,9H,10H,10H-perfluorodecane $\left(\mathrm{I}_{-} \mathrm{C}_{2} \mathrm{H}_{4}-\mathrm{C}_{6} \mathrm{~F}_{12^{-}}\right.$ $\left.\boldsymbol{C}_{2} \boldsymbol{H}_{4}-\boldsymbol{I}\right)$. The batch bismonoaddition of $\alpha, \omega$-diiodoperfluorohexane onto ethylene was performed in a $160 \mathrm{~mL}$ Hastelloy autoclave Parr System, equipped with a manometer, a rupture disk, inlet and outlet valves, and a mechanical anchor. An electronic device regulated and controlled both the stirring and the heating of the autoclave. The autoclave was left closed for $20 \mathrm{~min}$ and purged with 30 bars of nitrogen pressure to prevent any leakage, and degassed afterwards. Then, a $2 \mathrm{~mm} \mathrm{Hg}$ vacuum was operated for $15 \mathrm{~min}$. The initiator di-4-tert- 
butylcyclohexyl peroxydicarbonate $(4.22 \mathrm{~g}, 10 \mathrm{mmol})$ and $30.13 \mathrm{~g}(54.2 \mathrm{mmol})$ of $\mathrm{I}_{-} \mathrm{C}_{6} \mathrm{~F}_{12}-\mathrm{I}$ in dry tert-butanol $(40 \mathrm{~mL})$ were introduced via a funnel tightly connected to the introduction valve. Next, ethylene $(3.0 \mathrm{~g}, 0.1 \mathrm{~mol})$ was introduced by double weighing. The autoclave was heated up to $50{ }^{\circ} \mathrm{C}$ for $7 \mathrm{hrs}$ and an increase of pressure from 5 to 13 bars was noted followed by a drop of pressure to 4 bars. Then, the autoclave was cooled to room temperature and put into an ice bath. After releasing the unreacted monomer, the autoclave was opened and tertbutanol was evaporated. The total product mixture was solubilized in THF and then precipitated from cold pentane. The fluorinated diiodo product was filtered, washed, and dried at room temperature under a $20 \mathrm{mmHg}$ vacuum for $24 \mathrm{hrs}$ leading to a white powder in $80 \%$ yield. FT IR $\left(\mathrm{KBr}, \mathrm{cm}^{-1}\right): 1138\left(\mathrm{v}_{\mathrm{C}-\mathrm{F}}\right) .{ }^{1} \mathrm{H} \mathrm{NMR}\left(400 \mathrm{MHz}, \mathrm{CDCl}_{3}\right): \delta(\mathrm{ppm}) 3.2\left(4 \mathrm{H}, \mathrm{t},{ }^{3} J_{\mathrm{HH}}=\right.$ 7.01 Hz), $2.6(4 \mathrm{H}, \mathrm{m}) .{ }^{19} \mathrm{~F} \mathrm{NMR}\left(400 \mathrm{MHz} ; \mathrm{CDCl}_{3}\right) \delta(\mathrm{ppm})-115.2(4 \mathrm{~F}, \mathrm{~m}),-121.8(4 \mathrm{~F}, \mathrm{~m})$, $-123.8(4 \mathrm{~F}, \mathrm{~m})$.

Synthesis of 1,10-diazido-1H,1H,2H,2H,9H,9H,10H,10H-perfluorodecane $\left(\mathrm{N}_{3}-\mathrm{C}_{2} \mathrm{H}_{4}-\mathrm{C}_{6} \mathrm{~F}_{12}\right.$

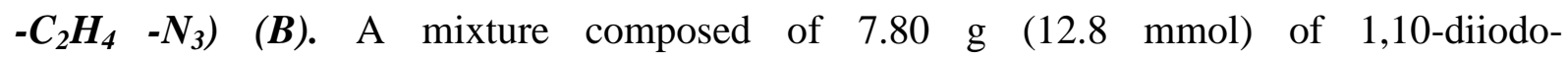
1H,1H,2H,2H,9H,9H,10H,10H-perfluorodecane and $2.21 \mathrm{~g}(30.8 \mathrm{mmol})$ sodium azide dissolved in DMSO $(25 \mathrm{~mL})$ and water $(1 \mathrm{~mL})$ was stirred at $50{ }^{\circ} \mathrm{C}$ for $48 \mathrm{hrs}$. Then, the reaction mixture was poured into water $(1 \mathrm{~L})$ and was extracted with diethyl ether. This procedure was repeated twice. The organic layer was washed with water twice, $10 \%$ sodium sulfite solution twice, water ( 3 times), brine, then dried over $\mathrm{MgSO}_{4}$, and filtered. The solvent was evaporated under reduced pressure to give $3.4 \mathrm{~g}$ of a pale green oil. The yield of the fluorinated diazide was $60 \%$. FT IR $\left(\mathrm{KBr}, \mathrm{cm}^{-1}\right): 2100\left(v_{\mathrm{N} 3}\right), 1138\left(\mathrm{v}_{\mathrm{C}-\mathrm{F}}\right) .{ }^{1} \mathrm{H}$ NMR (400 $\left.\mathrm{MHz}, \mathrm{CDCl}_{3}\right): \delta(\mathrm{ppm}) 3.5\left(4 \mathrm{H}, \mathrm{t},{ }^{3} \mathrm{~J}_{\mathrm{HH}}=7.07 \mathrm{~Hz},\right), 2.3(4 \mathrm{H}, \mathrm{m}) .{ }^{19} \mathrm{~F}$ NMR $(400 \mathrm{MHz}$, $\left.\mathrm{CDCl}_{3}\right): \delta(\mathrm{ppm})-113.5(4 \mathrm{~F}, \mathrm{~m}),-121.8(4 \mathrm{~F}, \mathrm{~m}),-123.8(4 \mathrm{~F}, \mathrm{~m})$. 
Copolymer (1). To a $100 \mathrm{~mL}$ three-neck round-bottom flask equipped with a magnetic stirrer, were added copper bromide $(57.1 \mathrm{mg}, 0.4 \mathrm{mmol})$ and 2,2'-bipyridine (bpy) (141.7 mg, 0.8 mmol). The flask was sealed with three septa and the suspension was purged with dry nitrogen for $60 \mathrm{~min}$. In experiment 1 (Table 2) 1,10-diazido- $1 \mathrm{H}, 1 \mathrm{H}, 2 \mathrm{H}, 2 \mathrm{H}, 9 \mathrm{H}, 9 \mathrm{H}, 10 \mathrm{H}, 10 \mathrm{H}-$ perfluorodecane $(2.24 \mathrm{~g}, 5.10 \mathrm{mmol})$ and the aromatic dialkyne $(2.03 \mathrm{~g}, 4.94 \mathrm{mmol})$ in $20 \mathrm{~mL}$ of THF were syringed through a septum.

The resulting mixture was stirred at room temperature for $48 \mathrm{hrs}$. The final mixture was passed through a short silica column to remove the copper catalyst. The mixture was precipitated from cold diethyl ether $(500 \mathrm{~mL})$. After filtration, the precipitate was dried under vacuum to give $1.5 \mathrm{~g}$ of a colorless gum (Yield= $60 \%)$. RAMAN shift $\left(\mathrm{cm}^{-1}\right)$ : $904\left(v_{\mathrm{C}-\mathrm{F}}\right)$ 1000-1200 ( $\left.v_{\text {aromatic C-H in-plane bend }}\right), 971,1253,1384$ and 1487 ( $\left.v_{\text {triazole ring stretch }}\right) 1480\left(v_{\mathrm{C}-\mathrm{O}}\right)$, 1600 ( $v_{\text {aromatic ring stretch). }}{ }^{1} \mathrm{H}$ NMR (400 MHz, $\mathrm{d}_{6}$-acetone): $\delta(\mathrm{ppm}) 3.0(4 \mathrm{H}, \mathrm{m}), 4.9\left(4 \mathrm{H}, \mathrm{t},{ }^{3} J\right.$ $\mathrm{HH}=7.07 \mathrm{~Hz}), 5.3(4 \mathrm{H}, \mathrm{s}), 7.4\left(4 \mathrm{H}, \mathrm{d},{ }^{3} J_{\mathrm{HH}}=6.90 \mathrm{~Hz}\right), 7.2\left(4 \mathrm{H}, \mathrm{d},{ }^{3} J_{\mathrm{HH}}=7.01 \mathrm{~Hz}\right), 8.4(2 \mathrm{H}$, s). ${ }^{19}$ F NMR (400 MHz, d 6 -acetone): $\delta$ (ppm) -63.2 (6 F, s), -113.5 (4 F, m), -121.8 (4 F, m), 124.3 (4 F, m). ${ }^{13} \mathrm{C}$ NMR (400 MHz, $\mathrm{d}_{6}$-acetone): $\delta$ (ppm) 159.8, 144.1, 132.2, 126.1, 125.3, $115.3,62.4,42.9$.

Synthesis of poly(bis-(ether bisphenol AF) diacetylene) by Hay coupling (3). The same mixture of copper bromide (57.1 $\mathrm{mg}, 0.4 \mathrm{mmol})$ and 2,2'-bipyridine (bpy) (141.7 mg, 0.8 mmol) was prepared as above and purged with dry nitrogen for $40 \mathrm{~min}$. A solution of the aromatic dialkyne (A) $(0.50 \mathrm{~g}, 1.21 \mathrm{mmol})$ in THF $(10 \mathrm{~mL})$ was syringed in the flask. The resulting mixture was stirred at room temperature for $48 \mathrm{hrs}$. The polymer was then precipitated in $400 \mathrm{~mL}$ of methanol. The white powder was filtered, precipitated from methanol twice, and dried at room temperature under a $20 \mathrm{mmHg}$ vacuum for $24 \mathrm{hrs}$ (Yield= $65 \%)$. RAMAN shift $\left(\mathrm{cm}^{-1}\right): 904\left(v_{\mathrm{C}-\mathrm{F}}\right), 1000-1200$ ( $\left.v_{\text {aromatic C-H in-plane bend }}\right), 1480\left(v_{\mathrm{C}-\mathrm{O}}\right), 1600$ 
( $\left.v_{\text {aromatic ring stretch }}\right), 2264\left(v_{\mathrm{C}=\mathrm{C}}\right) .{ }^{1} \mathrm{H} \mathrm{NMR}\left(400 \mathrm{MHz}, \mathrm{d}_{6}\right.$-acetone $): \delta$ ppm $6.8\left(4 \mathrm{H}, \mathrm{d},{ }^{3} J_{\mathrm{HH}}=\right.$ $8.55 \mathrm{~Hz}), 7.4\left(4 \mathrm{H}, \mathrm{d},{ }^{3} J_{\mathrm{HH}}=8.55 \mathrm{~Hz}\right), 4.8\left(4 \mathrm{H}, \mathrm{d},{ }^{4} J_{\mathrm{HH}}=2.30 \mathrm{~Hz}\right) .{ }^{19} \mathrm{~F}$ NMR $\left(400 \mathrm{MHz}, \mathrm{d}_{6^{-}}\right.$ acetone): $\delta(\mathrm{ppm})-63.2(6 \mathrm{~F}, \mathrm{~m}) .{ }^{13} \mathrm{C}$ NMR (400 MHz, $\mathrm{d}_{6}$-acetone): $\delta \mathrm{ppm} \mathrm{158.8,} \mathrm{132.2,}$ 126.7, 79.2, 76.0, 71.1, 56.7.

\section{Synthesis of poly(1,10-triazolofluorodecane-co-methyleneether hexafluorobisphenol AF)}

\section{Copolymer combining “Click” reaction and Hay Coupling (4).}

A $100 \mathrm{~mL}$ three-neck round-bottom flask equipped with a magnetic stirrer was filled with a mixture of copper (I) bromide (57.1 mg, $0.4 \mathrm{mmol})$, copper (II) bromide (25.2 mg, $0.2 \mathrm{mmol}$ ) and 2,2'-bipyridine (bpy) (141.7 mg, $0.8 \mathrm{mmol})$. The flask was then sealed with three septa. 1,10-diazido- $1 \mathrm{H}, 1 \mathrm{H}, 2 \mathrm{H}, 2 \mathrm{H}, 9 \mathrm{H}, 9 \mathrm{H}, 10 \mathrm{H}, 10 \mathrm{H}$-perfluorodecane $(0.53 \mathrm{~g}, 1.20 \mathrm{mmol})$ and the aromatic dialkyne (A) $(0.50 \mathrm{~g}, 4.9 \mathrm{mmol})$ in $20 \mathrm{~mL}$ of THF were syringed through a septum. The resulting mixture was stirred at room temperature for $48 \mathrm{hrs}$, then passed through silica powder to remove the copper catalyst. The mixture was precipitated from cold diethyl ether $(500 \mathrm{~mL})$. After filtration, the precipitate was dried under vacuum to give $0.5 \mathrm{~g}$ of a colorless gum (Yield= $50 \%)$. RAMAN shift $\left(\mathrm{cm}^{-1}\right)$ : $904\left(v_{\mathrm{C}-\mathrm{F}}\right)$ 1000-1200 (varomatic C-H in-plane bend), 971, 1253, 1384 and 1487 ( $\left.v_{\text {triazole ring stretch }}\right) 1480\left(v_{\mathrm{C}-\mathrm{O}}\right), 1600$ ( $\left.v_{\text {aromatic ring stretch }}\right), 2264\left(v_{\mathrm{C} \equiv \mathrm{C}}\right) .{ }^{1} \mathrm{H}$

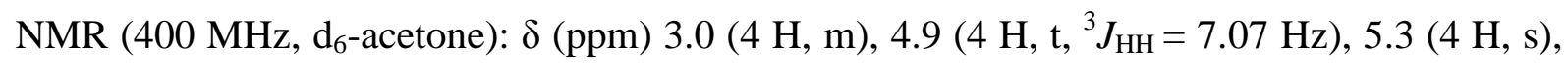
$7.4\left(4 \mathrm{H}, \mathrm{d},{ }^{3} \mathrm{~J}_{\mathrm{HH}}=6.90 \mathrm{~Hz}\right), 7.2\left(4 \mathrm{H}, \mathrm{d},{ }^{3} \mathrm{~J}_{\mathrm{HH}}=7.01 \mathrm{~Hz}\right), 8.4(2 \mathrm{H}, \mathrm{s}) .{ }^{19} \mathrm{~F} \mathrm{NMR}(400 \mathrm{MHz}$, $\mathrm{d}_{6}$-acetone): $\delta(\mathrm{ppm})-63.2(6 \mathrm{~F}, \mathrm{~s}),-113.5(4 \mathrm{~F}, \mathrm{~m}),-121.8(4 \mathrm{~F}, \mathrm{~m}),-124.3(4 \mathrm{~F}, \mathrm{~m}) .{ }^{13} \mathrm{C}$ NMR (400 MHz, $\mathrm{d}_{6}$-acetone): $\delta$ (ppm) 159.8, 144.1, 132.2, 126.1, 125.3, 115.3, 62.4, 42.9 .

\section{RESULTS AND DISCUSSION}

\section{Monomer Synthesis}

Telechelic $\alpha, \omega$-dipropargyl ether hexafluorobisphenol AF (A) was prepared in satisfactory yield from propargyl bromide and hexafluoro bisphenol AF as reported by Dirlikov et al. ${ }^{8-e}$ 
and Hay ${ }^{53}$ Characteristic features of monomer (A) were evidenced by RAMAN and NMR spectroscopies. Characteristic band of C-F vibration appeared at $904 \mathrm{~cm}^{-1}$ in the RAMAN spectrum [Figure S1 in Electronic Supporting Information (ESI)]. The peaks observed in the $1100-1300 \mathrm{~cm}^{-1}$ range and at $1600 \mathrm{~cm}^{-1}$ were attributed to aromatic $\mathrm{C}-\mathrm{H}$ in-plane bend and aromatic ring stretch, ${ }^{54}$ respectively. An intense band at $2133 \mathrm{~cm}^{-1}$ characteristic of the triple bond vibration of acetylene moieties ${ }^{54}$ was also noted. Moreover, the two characteristic signals of the acetylenic carbon atoms were found in the ${ }^{13} \mathrm{C}$ NMR spectrum at 75.4 and 78.6 ppm while the aliphatic carbon in alpha position $\left(\mathrm{CH}_{2} \mathrm{O}\right)$ appeared at $56.7 \mathrm{ppm}$. The ${ }^{1} \mathrm{H}$ NMR spectrum exhibited the protons in the ethynyl and $\mathrm{CH}_{2} \mathrm{O}$ groups as a triplet at $3.1 \mathrm{ppm}$ and a doublet at $4.8 \mathrm{ppm}$, respectively.

\section{1,10-Diazido-1H,1H,2H,2H,9H,9H,10H,10H-perfluorodecane (B) was obtained from} commercially available $\alpha, \omega$-diiodoperfluorohexane in two steps: i) batch bismonoaddition of ethylene onto $\alpha, \omega$-diiodoperfluorohexane and ii) nucleophilic substitution of iodine atoms of the resulting 1,10-diiodo- $1 \mathrm{H}, 1 \mathrm{H}, 2 \mathrm{H}, 2 \mathrm{H}, 9 \mathrm{H}, 9 \mathrm{H}, 10 \mathrm{H}, 10 \mathrm{H}$-perfluorodecane in the presence of sodium azide. Step 1 was adapted from the reaction of Manseri et al., ${ }^{55}$ but carrying out the reaction at $50{ }^{\circ} \mathrm{C}$ for $8 \mathrm{hrs}$ with di-4-tert-butylcyclohexyl peroxydicarbonate as the initiator. This led to 1,10-diiodo- $1 \mathrm{H}, 1 \mathrm{H}, 2 \mathrm{H}, 2 \mathrm{H}, 9 \mathrm{H}, 9 \mathrm{H}, 10 \mathrm{H}, 10 \mathrm{H}$-perfluorodecane $\left(\mathrm{I}-\mathrm{C}_{2} \mathrm{H}_{4}-\mathrm{C}_{6} \mathrm{~F}_{12}-\mathrm{C}_{2} \mathrm{H}_{4}\right.$ I) in $80 \%$ yield. Step 2 was based on Malik et $a l .{ }^{56}$ pioneering synthesis of fluorinated diazides $($ yield $=40 \%$ ). Indeed, the reaction conditions were optimized to improve the yield. Particularly, temperature, reaction time, and initial $\left[\mathrm{NaN}_{3}\right]_{0} /\left[\mathrm{IC}_{2} \mathrm{H}_{4} \mathrm{C}_{6} \mathrm{~F}_{12} \mathrm{C}_{2} \mathrm{H}_{4} \mathrm{I}\right]_{0}$ molar ratio were monitored (Table 1). When the reaction was carried out with an excess of $\mathrm{NaN}_{3}(3$ or 6 mole equiv., entries 1 and 2, Table 1) at room temperature, it proceeded smoothly and was not complete (30\% and $40 \%$ yields, respectively, even after $96 \mathrm{hrs}$ ), suggesting that the amount of excess $\mathrm{NaN}_{3}$ was not a decisive parameter at room temperature. Instead, when the reaction was carried out at $50{ }^{\circ} \mathrm{C}$ with a 3 -fold molar excess of $\mathrm{NaN}_{3}$ with respect to $\mathrm{I}_{-} \mathrm{C}_{2} \mathrm{H}_{4}-\mathrm{C}_{6} \mathrm{~F}_{12}-$ 
$\mathrm{C}_{2} \mathrm{H}_{4}$-I, it reached completion after 48 hrs (entry 3, Table 1), yielding, after purification, 60\% of 1,10 -diazido- $1 \mathrm{H}, 1 \mathrm{H}, 2 \mathrm{H}, 2 \mathrm{H}, 9 \mathrm{H}, 9 \mathrm{H}, 10 \mathrm{H}, 10 \mathrm{H}$-perfluorodecane $\left(\mathrm{N}_{3}-\mathrm{C}_{2} \mathrm{H}_{4}-\mathrm{C}_{6} \mathrm{~F}_{12}-\mathrm{C}_{2} \mathrm{H}_{4}-\mathrm{N}_{3}\right)$ (B).

\section{Insert Table 1}

The ${ }^{19} \mathrm{~F}$ NMR spectrum of telechelic fluorinated diazido compound (Figure S2 in ESI) revealed the low-field shift of the multiplet assigned to the difluoromethylene adjacent to methylene group from $-114.8 \mathrm{ppm}$ to $-113.6 \mathrm{ppm}$, while the other fluoromethylene signals did not shift, as expected. The ${ }^{1} \mathrm{H}$ NMR spectrum (Figure S3 in ESI) showed the low-field shift of the $-\mathrm{CH}_{2}-\mathrm{X}$ terminal group from $3.2 \mathrm{ppm}(\mathrm{X}=\mathrm{I})$ to $3.4 \mathrm{ppm}\left(\mathrm{X}=\mathrm{N}_{3}\right)$, because of the higher electron withdrawing effect of azido group with respect to that of iodine. Finally, the FT IR spectrum (Figure S4 in ESI) showed a strong sharp frequency at $2100 \mathrm{~cm}^{-1}$, characteristic of the azide function. ${ }^{56}$ The other expected frequencies, corresponding to the C-F vibrations of the perfluorohexane central group, were observed in the range $1100-1200 \mathrm{~cm}^{-1}$.

\section{Polycondensation of $\alpha, \omega$-dipropargyl ether hexafluorobisphenol AF (A) with 1,10- diazido-1H,1H,2H,2H,9H,9H,10H,10H-perfluorodecane (B)}

Cummins et al. $^{52 \mathrm{a}}$ reported that during the grafting of polystyrene derivative (in a confined medium) onto a surface by "Click" reaction, a homocoupling (Hay Coupling) of the terminal alkynes was also observed. Starting from this statement, we have decided to determine the required experimental conditions to promote further the homocoupling of alkyne moieties in (A) with the objective to produce a block copolymer. Hence, it was of interest to investigate a series of reactions in which the experimental conditions were carefully selected to favor one reaction with regards to the others (Table 2). 
Scheme 2 displays the predicted structure of the product resulting from the stoechiometric polycondensation by the azide/alkyne "Click" reaction. Similar reaction conditions as those reported by Lutz et al. ${ }^{57 \mathrm{a}-\mathrm{b}}$ were used.

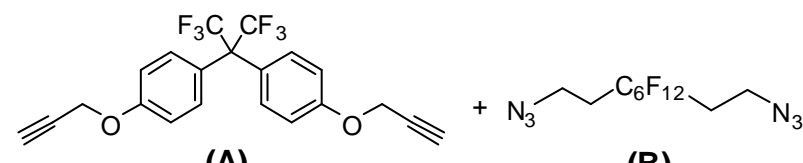

(A)

(B)

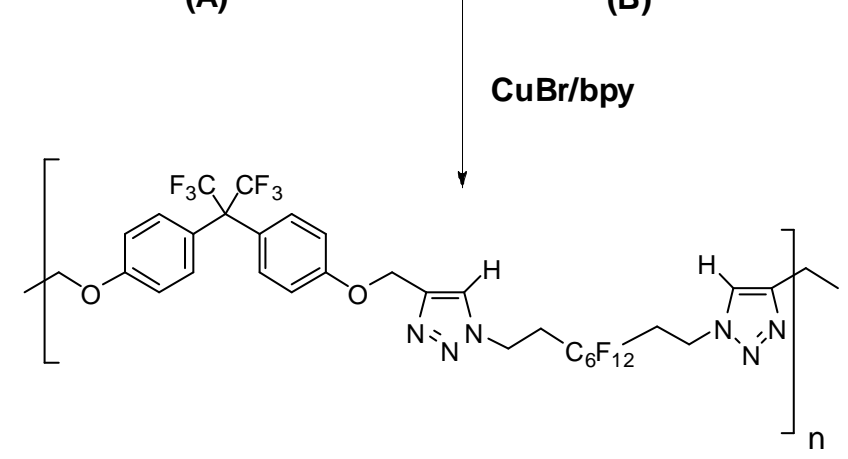

Scheme 2. Polycondensation reaction of telechelic 1,10-diazido$1 \mathrm{H}, 1 \mathrm{H}, 2 \mathrm{H}, 2 \mathrm{H}, 9 \mathrm{H}, 9 \mathrm{H}, 10 \mathrm{H}, 10 \mathrm{H}$-perfluorodecane (B) with $\alpha, \omega$-dipropargyl ether hexafluorobisphenol AF (A) by the azide/alkyne "Click" reaction (bpy stands for 2,2'bipyridine).

The polycondensation was performed in THF at room temperature, using $0.4 \mathrm{mmol}$ of $\mathrm{CuBr}$ and 0.8 mmol. of 2,2'-bipyridine (bpy). The choice of the bpy ligand was driven by a recent extensive study from Matyjaszewski's group ${ }^{22}$ who reported that the nature of aminated ligands induced a neat effect onto kinetics in the following increasing order of magnitude: N,N,N',N",N"-pentamethyldiethylenetriamine (PMEDTA) (x230) > N,N,N',N",N"',N"'hexamethyltriethylenetetraamine (HMTETA) $(\mathrm{x} 55)>\operatorname{tris}\left[\right.$ dimethylamino)ethyl]amine $\left(\mathrm{Me}_{6^{-}}\right.$ TREN) > 2,2':2',6"-terpyridine (tpy) (x8.6) > tris[(2-pyridyl)methyl]amine (TPMA) (x1.7) > no ligand $(\mathrm{x} 1)>2,2$ '-bipyridine (bpy) $(\mathrm{x} 0.43)$. The increase of the reaction rate by aminated aliphatic ligands is partially explained by their strong basic behavior, which is higher than that of aromatic amines. Indeed, various authors ${ }^{22-23}$ have noted an increase of the "Click" reaction rate in the presence of a base, which is assumed to favor the formation of copper (I) acetylide 
complexes. Moreover, aliphatic amines are more labile than ligands derived from pyridine, thus making easier the coordination of azide by copper (I) acetylide. ${ }^{25}$ Here, 2,2'-bipyridine was used with the objective to slow down the rate of the "Click" reaction.

Experiments 1 and 2 were focused on the influence of concentrations of the reactants onto the behavior of the polycondensation, under quasi inert atmosphere, by simply varying the $[\text { dipropargyl }]_{\mathrm{o}} /\left[\right.$ diazido $_{\mathrm{o}}(\mathbf{A}) /(\mathbf{B})$ molar ratio. Once the reactions completed, the total product mixtures were characterized by size exclusion chromatography (SEC). The SEC chromatograms corresponding to Experiments 1 and 2 in Table 2 are presented in Figure 1.
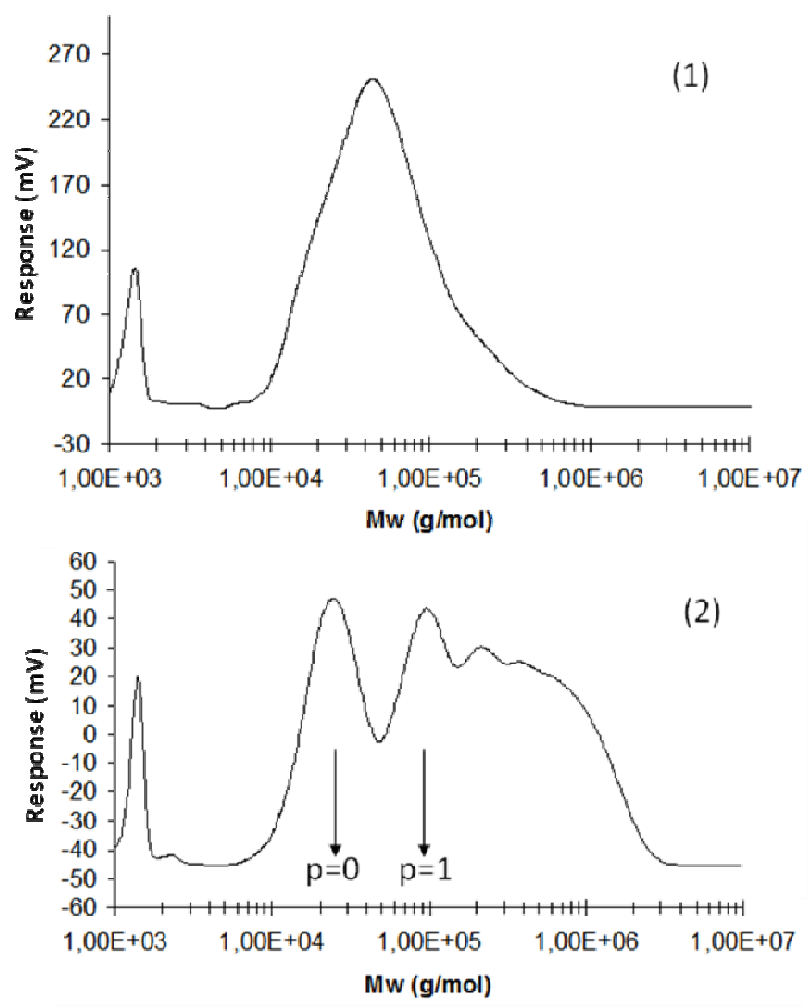

Figure 1. SEC (Size Exclusion Chromatography) chromatograms of copolymers (1) $(r=$ 0.97) (upper spectrum) and (2) $(r=0.99)$ (lower spectrum) calibrated with Poly(styrene) standards.

Interestingly, the obtained SEC chromatograms evidenced a dependence of the molecular weight distributions versus (A)/(B) molar ratio values. In experiment 1 , an excess of (B) with 
respect to (A) ( $\left.\mathrm{n}_{\alpha, \omega-\text {-dipropargyl ether bisphenol } \mathrm{AF}} / \mathrm{n}_{1,10 \text {-diazido-1H,1H,2H,2H,9H,9H,10H,10H-perfluorodecane }}=0.97\right)$ resulted in a monomodal distribution centered at $\mathrm{Mn}=37,000 \mathrm{~g} / \mathrm{mol}$ with a polydispersity index $=1.8$ (in polystyrene standards, Figure $1-1$ ). The theoretical value of the average degree of polymerization (DPn) could be assessed by the Flory equation:

$$
\mathrm{DPn}=\frac{1+r}{1+r-2 p r}
$$

where $p$ is the extent of the reaction and $r$ the initial molar ratio between the reactive functions (with $r \leq 1$ ).

When $r=0.97$ and $p=1$ (excess of telechelic diazido compound), i.e. Experiment 1 (Table 2), the corresponding theoretical DPn value is 65. As the average molecular weight of monomeric unit is $426 \mathrm{~g} / \mathrm{mol}$, the resulting theoretical Mn value for $r=0.97$ is $28,000 \mathrm{~g} / \mathrm{mol}$, which is in close agreement with the experimental value of $37,000 \mathrm{~g} / \mathrm{mol}$. To confirm the high molecular weight of copolymer (1), the intrinsic viscosity was assessed in acetone at room temperature, giving $0.40 \mathrm{dL} \cdot \mathrm{g}^{-1}$. This value confirms that "Click" reaction was very efficient, in spite of the excess of $(\mathbf{B})$ with respect to $(\mathbf{A})(r=0.97)$.

However, the correlation of intrinsic viscosity with molecular weight for this original linear polymer could not be achieved by the Mark and Houwink equation since $\mathrm{K}$ and $\alpha$ parameters have not been reported. In this case, the polycondensation seems to proceed via azide/alkyne "Click" reaction as displayed in Scheme 3, and copolymer (1) is expected to exhibit a microstructure based on alternating aromatic and fluorinated units, bearing azido end groups. 


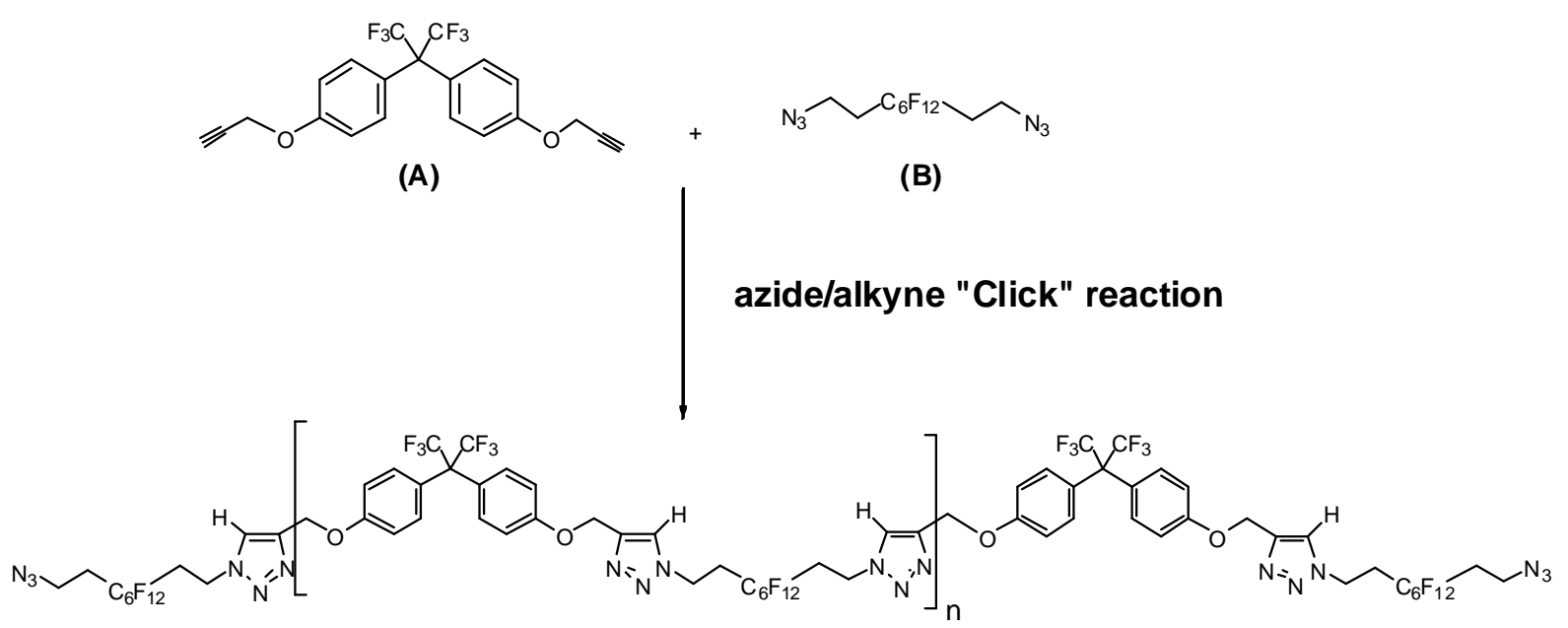

(1)

Scheme 3. Polycondensation reaction between $\alpha, \omega$-dipropargyl ether hexafluoro bisphenol $\mathrm{AF}$ (A) and a slight excess of telechelic fluorinated diazido (B) following the azide/alkyne "Click" reaction mechanism.

The ${ }^{1} \mathrm{H}$ and ${ }^{13} \mathrm{C}$ NMR of copolymer (1) were consistent with the proposed structure (Figure S5 and S6 in ESI). The triazole ring formation was evidenced by the presence of characteristic signals at $8.5 \mathrm{ppm}\left({ }^{1} \mathrm{H} \mathrm{NMR}\right)$ and at 144.1 and $125.3 \mathrm{ppm}\left({ }^{13} \mathrm{C} \mathrm{NMR}\right) .{ }^{58}$ Furthermore, strong low-field shifts of the aliphatic protons were noted for both precursors in the ${ }^{1} \mathrm{H}$ NMR spectrum. For example, the methylene groups of the fluorinated diazido reactant shifted from 3.6 to $4.9 \mathrm{ppm}$ and from 2.3 to $3.0 \mathrm{ppm}$ in polymer (1). Similarly, the singlet attributed to the methylene group in $\mathrm{CH}_{2} \mathrm{O}$ underwent a low-field shift from 4.9 to 5.3 ppm after copolymerization. RAMAN spectroscopy provided additional structural evidence (Figure 2b), with bands at $971,1253,1384$ and $1487 \mathrm{~cm}^{-1}$ that are characteristic of the triazole ring stretch. ${ }^{59}$ No signal assigned to the triple bond vibration of acetylene moieties ${ }^{54}$ was observed at $2133 \mathrm{~cm}^{-1}$.

In Experiment 2, a small excess of $\alpha, \omega$-dipropargyl ether bisphenol AF (A) was added with respect to 1,10-diazido- $1 \mathrm{H}, 1 \mathrm{H}, 2 \mathrm{H}, 2 \mathrm{H}, 9 \mathrm{H}, 9 \mathrm{H}, 10 \mathrm{H}, 10 \mathrm{H}$-perfluorodecane $\left(\mathrm{n}_{\alpha, \omega \text {-dipropargyl ether bisphenol }}\right.$

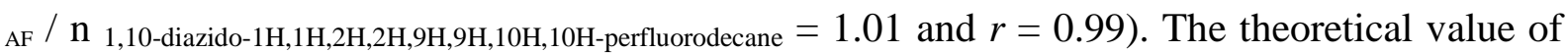
the average degree of polymerization assessed by the Flory equation was 199, leading to a theoretical Mn value of $85,000 \mathrm{~g} / \mathrm{mol}$. The SEC chromatogram (Figure 1-2) showed the 
presence of a polymodal distribution covering a wide range of molecular weights (from 50,000 to more than $200,000 \mathrm{~g} / \mathrm{mol}$ ). The high molecular weight of copolymer (2) was further confirmed by a higher intrinsic viscosity value of $0.60 \mathrm{dL} \cdot \mathrm{g}^{-1}$ (Experiment 2, Table 2). Here, a strong discrepancy between theoretical and experimental Mn values is observed. To explain this result, the reaction pathway depicted in Scheme 4 is proposed. The excess of (A) allows some Hay acetylenic homocoupling between the terminal alkyne groups of the copolymers generated by "Click" reaction. As a result, a high molecular weight copolymer exhibiting an original microstructure with bridging bisacetylene segments randomly distributed along the copolymer chain may be obtained.

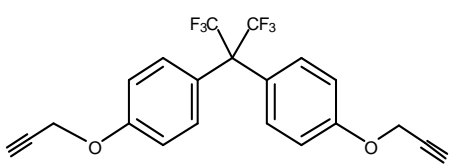

(A)

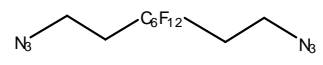

(B)

azide/alkyne "Click" reaction (Major)

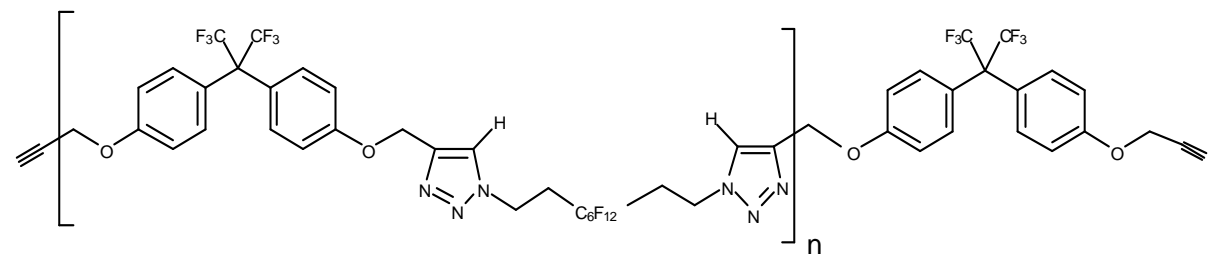

Hay Coupling (Minor)

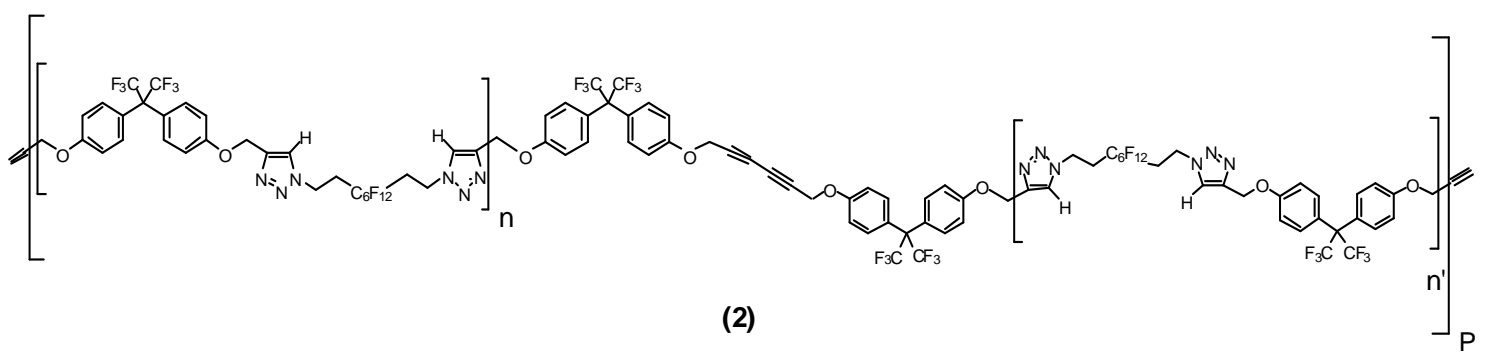


Scheme 4. Polycondensation reaction combining "Click" reaction (first step, major) and Hay Coupling (second step, minor) starting from $\alpha, \omega$-dipropargyl ether hexafluoro bisphenol AF (A) and 1,10-diazido-1H,1H,2H,2H,9H,9H,10H,10H-perfluorodecane (B).

${ }^{13} \mathrm{C}$ NMR spectroscopy analysis (Figure S6 in ESI) did not allow corroborating this mechanism as the characteristic peaks of the two diacetylenic carbons at 76.0 and $71.2 \mathrm{ppm}$ were not detected, probably due to the expected low content of such isolated bridging units with regards to the high molecular weight of the copolymeric chains. Also, to evidence the presence of diacetylenic units, copolymer (2) was characterized by RAMAN spectroscopy. Besides the signals observed in the range $971-1500 \mathrm{~cm}^{-1}$ and at $1600 \mathrm{~cm}^{-1}$ attributed to triazole ring stretch ${ }^{59}$ and aromatic ring stretch, ${ }^{54}$ respectively, the RAMAN spectrum (Figure 2.c) showed, a signal at $2264 \mathrm{~cm}^{-1}$, which may be assigned to the triple bond vibration of diacetylene moieties. ${ }^{60-61}$ No signal at $2133 \mathrm{~cm}^{-1}$, characteristic of the triple bond of terminal acetylene ${ }^{54}$ was noted.

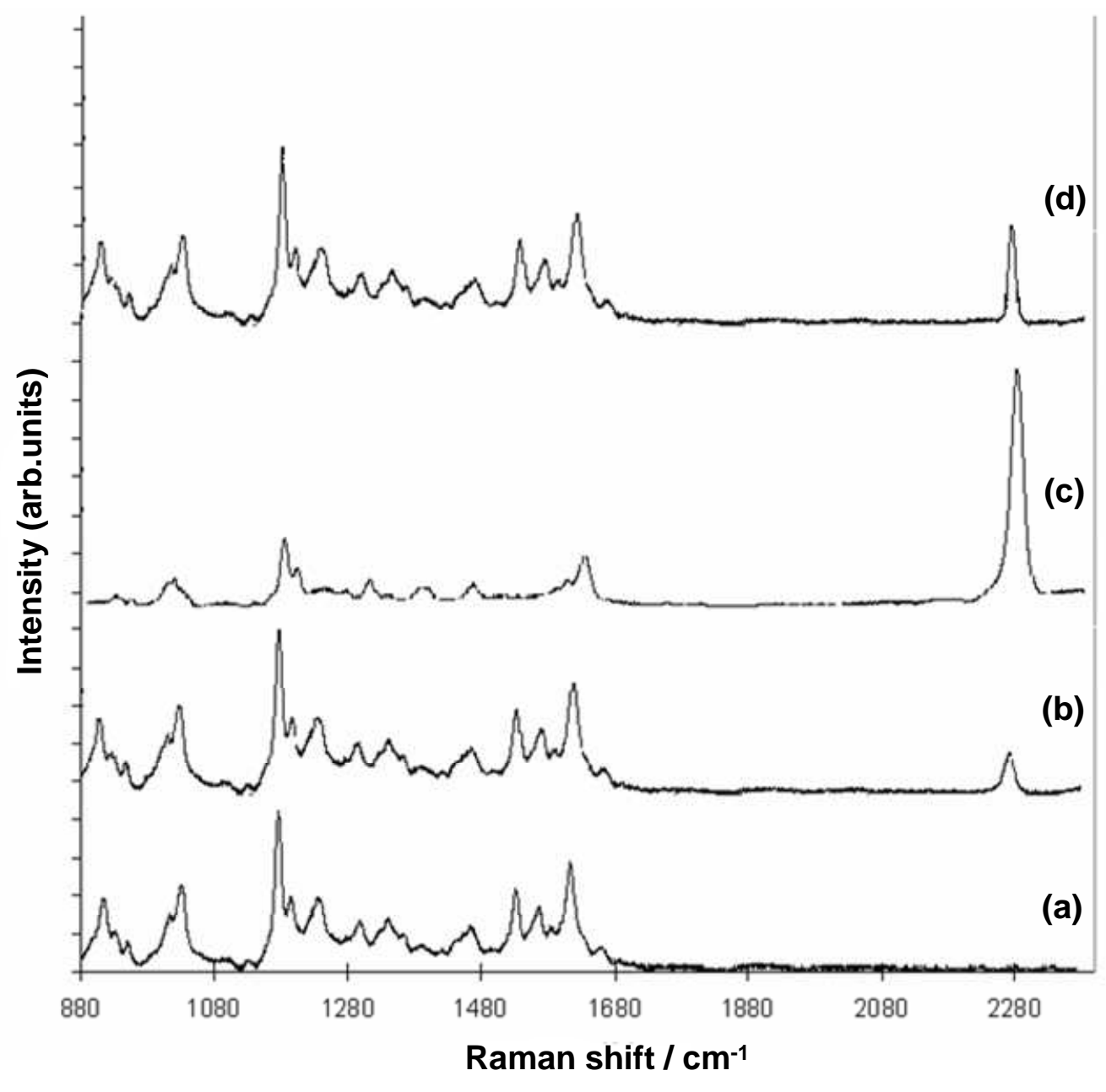


Figure 2. RAMAN spectra of (a) copolymer (1), (b) copolymer (2), (c) homopolymer (3) and (d) copolymer (4) in the $880-2300 \mathrm{~cm}^{-1}$ range.

To further demonstrate that Hay Coupling may indeed occur in such an oxygen poor atmosphere, a third reaction was carried out in the absence of bisazido compound (Experience 3, Table 2), under conditions similar to those used for the azide/alkyne "Click" reaction in Experiments 1 and 2 (Scheme 5).

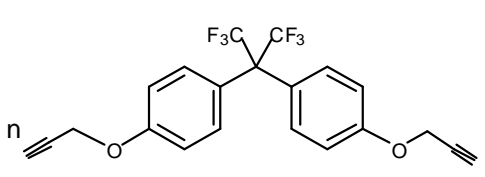

(A)

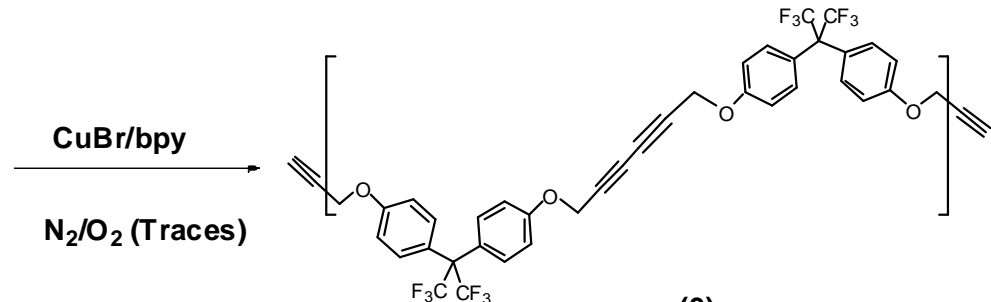

(3)

Scheme 5. Synthesis of poly(bis-(ether bisphenol AF) diacetylene) by Hay Coupling of $\alpha, \omega-$ dipropargyl ether hexafluoro bisphenol AF (A) (bpy means for 2,2'-bipyridine).

Homopolymer (3) was isolated as a white fibrous material and showed excellent solubility in THF. The weight-average molecular weights as determined by size exclusion chromatography relative to polystyrene standards ranged from 42,000 to $200,000 \mathrm{~g} / \mathrm{mol}$ (Figure S7 in ESI).

The ${ }^{1} \mathrm{H}$ and ${ }^{13} \mathrm{C}$ NMR spectra of homopolymer (3) were consistent with the assigned structure. No residual ethynyl protons due to unreacted acetylene groups were observed for the polymer by ${ }^{1} \mathrm{H}$ NMR (Figure S8 in ESI). The ${ }^{13} \mathrm{C}$ NMR spectra also showed that the terminal ethynyl carbons were converted into diacetylenic carbons after polymerization. For example, two diacetylenic carbons at 76.0 and $71.1 \mathrm{ppm}$ in the spectrum of homopolymer (3) (Figure S9 in ESI) replaced the two ethynyl carbons at 78.6 and $75.4 \mathrm{ppm}$ that were observed in the spectrum of monomer (A). In the RAMAN spectrum (Figure 2-d), the intense band corresponding to the triple bond vibration of diacetylene moieties was observed at $2264 \mathrm{~cm}^{-1}$ .$^{60-61}$ These results evidence that the Hay Coupling reaction could be initiated in the presence of oxygen traces. 
The presence of a band at $2264 \mathrm{~cm}^{-1}$ in the RAMAN spectra of both copolymer (2) and homopolymer (3), which is assigned to diacetylenic moieties, brings evidence that some acetylene homocoupling occurred during the synthesis of copolymer (2). The difference of intensity of this characteristic signal observed between the two spectra is representative of the low content of such isolated bridging units in copolymer (2) with regards to the high molecular weight of the copolymeric chains. Hence, it is worth considering that Hay Coupling occurred as a side reaction (Scheme 4, second step) when the "Click" reaction was carried out with an excess of alkyne as in the case of Experiment 2, in agreement with the work of Cummins et al.. ${ }^{52 \mathrm{a}}$

Consequently, these first three experiments (Table 2) enabled us to target the experimental conditions (absence of copper II reductive agent, ligand based on pyridine derivative, and alkyne functions in excess) in which Hay homocoupling of terminal alkynes may occur when performing azide-alkyne "Click" reaction.

This led us to implement the synthesis of an original fluorine-containing poly(alkyl aryl) ether bearing a block structure by promoting competition between "Click" reaction and Hay homocoupling.

Copper (II) salts are known to induce initiation of Hay coupling by oxidation of copper (I) acetylide species. ${ }^{14}$ Hence, experiment 2 was repeated in the presence of oxygen and a copper (II) salt to favor Hay homocoupling (experiment 4, Table 2). A small excess of $\alpha, \omega$ dipropargyl ether bisphenol AF (A) was added with respect to 1,10-diazido1H,1H,2H,2H,9H,9H,10H,10H-perfluorodecane (B) (n a,o-dipropargyl ether bisphenol AF $/ \mathrm{n}$ 1,10-diazido$1 \mathrm{H}, 1 \mathrm{H}, 2 \mathrm{H}, 2 \mathrm{H}, 9 \mathrm{H}, 9 \mathrm{H}, 10 \mathrm{H}, 10 \mathrm{H}-$ perfluorodecane $=1.01$ and $\mathrm{r}=0.99)$. The suspension was purged with dry nitrogen for $10 \mathrm{~min}$ (Experiment 4, Table 2). Interestingly, the SEC chromatogram (Figure 3) exhibited a quasimonomodal distribution centered at $\mathrm{Mn}=60,000 \mathrm{~g} / \mathrm{mol}$ with a polydispersity 
index of 1.8 (polystyrene standards), as opposed to the multimodal distribution observed in Experiment 2. The corresponding value of intrinsic viscosity obtained was $0.43 \mathrm{dL} \cdot \mathrm{g}^{-1}$.

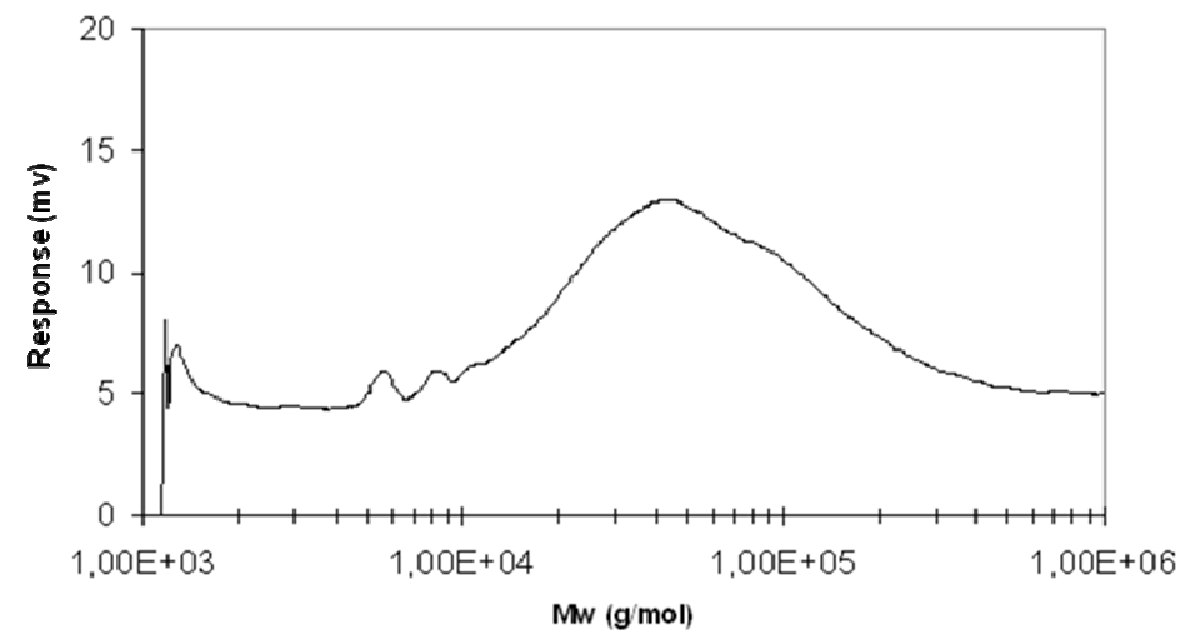

Figure 3. Size exclusion chromatogram of copolymer (4) (Experiment 4, Table 2).

The differences in molecular weight distributions observed by SEC between polymers (2) and (4) may be considered as an evidence that the new conditions favored Hay coupling enough to consume $\alpha, \omega$-dipropargyl ether bisphenol AF (A) species faster than in the course of the "Click" reaction. Consumption of the alkyne groups by Hay Coupling competitive to the azide-alkyne reaction would result in an evolution of the original $r$ ratio (excess of alkynes) towards an excess of azide groups (Scheme 6). As in Experiment 1, a monomodal distribution was observed.

The ${ }^{13} \mathrm{C}$ NMR spectrum (Figure S10 in ESI) of the obtained polycondensate did not provide evidence for the characteristic signals of diacetylenic carbons, suggesting that the size of the diacetylenic segments were still rather small $(m<<n)$.

A strong sharp frequency at $2100 \mathrm{~cm}^{-1}$ was observed in the FTIR spectrum (Figure S11 in ESI). This result is consistent with the presence of terminal azide functions, as depicted in Scheme 6. As in the case of copolymer (2), the RAMAN spectrum of copolymer (4) (Figure 2-e) exhibited the signal at $2264 \mathrm{~cm}^{-1}$ corresponding to the triple bond vibration of diacetylene moieties. 


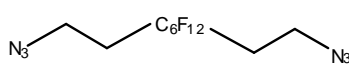

(B)

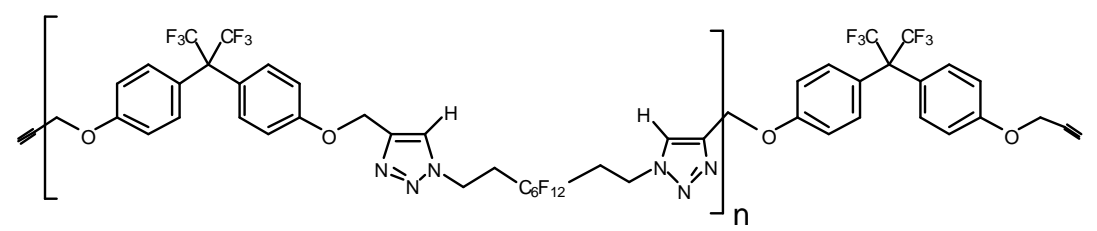

Azide/alkyne "Click" reaction

Hay coupling

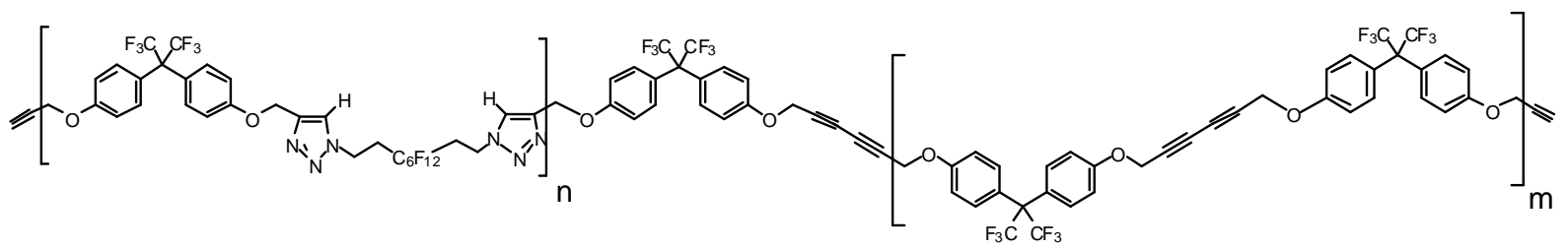

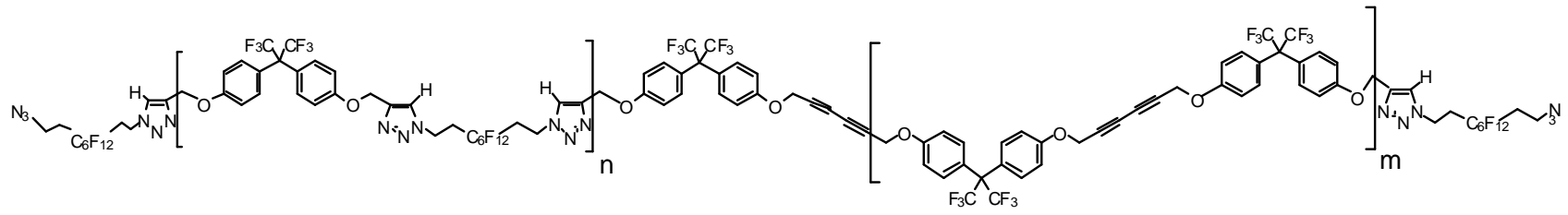

(4)

Scheme 6. Polycondensation mechanism proposed for the competition between Hay coupling and "Click" reactions starting from $\alpha, \omega$-dipropargyl ether hexafluoro bisphenol AF (A) and 1,10-diazido-1H,1H,2H,2H,9H,9H,10H,10H-perfluorodecane (B).

22 


\section{Thermal properties}

In the attempt to provide further evidence of the formation of blocks in polymer (4) in contrast to polymers (1) or (2), the thermal behaviors of the four polymers were investigated by differential scanning Calorimetry (DSC). The corresponding DSC thermograms are displayed in Figure 4.

All polymers were amorphous. Copolymers (1) and (2) clearly showed only one glass transition temperature centered at 60 and $90{ }^{\circ} \mathrm{C}$, respectively. The $30{ }^{\circ} \mathrm{C}$ difference may be explained by the higher molecular weight distribution of polymer (2). The diacetylenecontaining polymer synthesized from Experiment 3 exhibited an exothermic peak close to 183 ${ }^{\circ} \mathrm{C}$, which was attributed to thermally activated cross-linking of diacetylenes, as reported by several authors ${ }^{62-66}$.

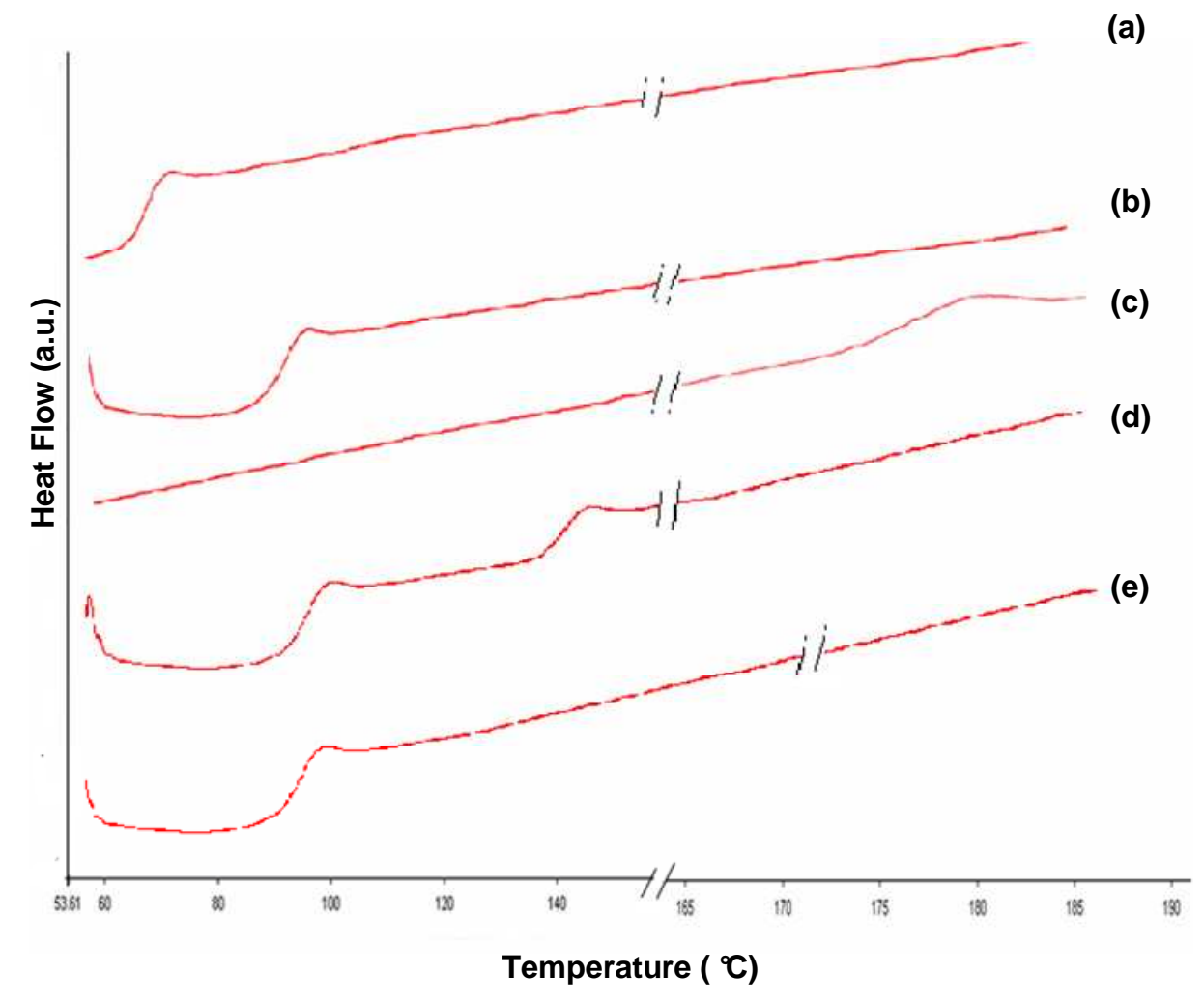

Figure 4. DSC thermograms of copolymer (1) (a); copolymer (2) (b), homopolymer (3) (c), copolymer (4) (d) before thermal curing, and of copolymer (4) (e) after thermal curing (15 $\min$ at $\left.170{ }^{\circ} \mathrm{C}\right)$. 
Interestingly, the DSC thermogram of copolymer obtained from experiment 4 exhibited two distinct thermal transitions centered at 90 and $152{ }^{\circ} \mathrm{C}$. The first transition $\left(90{ }^{\circ} \mathrm{C}\right)$ was assigned to a glass transition, as in copolymer (2). The second transition at $152{ }^{\circ} \mathrm{C}$ may be attributed to block that would be composed of diacetylene moieties. To define the nature of this second block, we performed the thermal curing at $175^{\circ} \mathrm{C}$ of copolymer (4). After 15 min, the polymer film became insoluble in all organic solvents. Interestingly, the DSC analysis of cured polymer (4) (Figure 4) evidenced the presence of one glass transition at $90{ }^{\circ} \mathrm{C}$. The second transition was not observed. Consequently, this transition could be attributed to the exothermic cross-linking of diacetylenes moieties in a poly(aryl) block.

To confirm the thermal cross-linking of diacetylenic moieties in copolymer (4), ultraviolet absorption spectra were recorded before and after thermal curing. In the UV spectrum of the uncured film, the presence of diacetylenes units was evidenced by an absorption band at 254 nm. ${ }^{66}$ The signals observed at 260 and $279 \mathrm{~nm}$ were assigned to triazole ring, ${ }^{67}$ while no absorption bands in the visible region were noted.

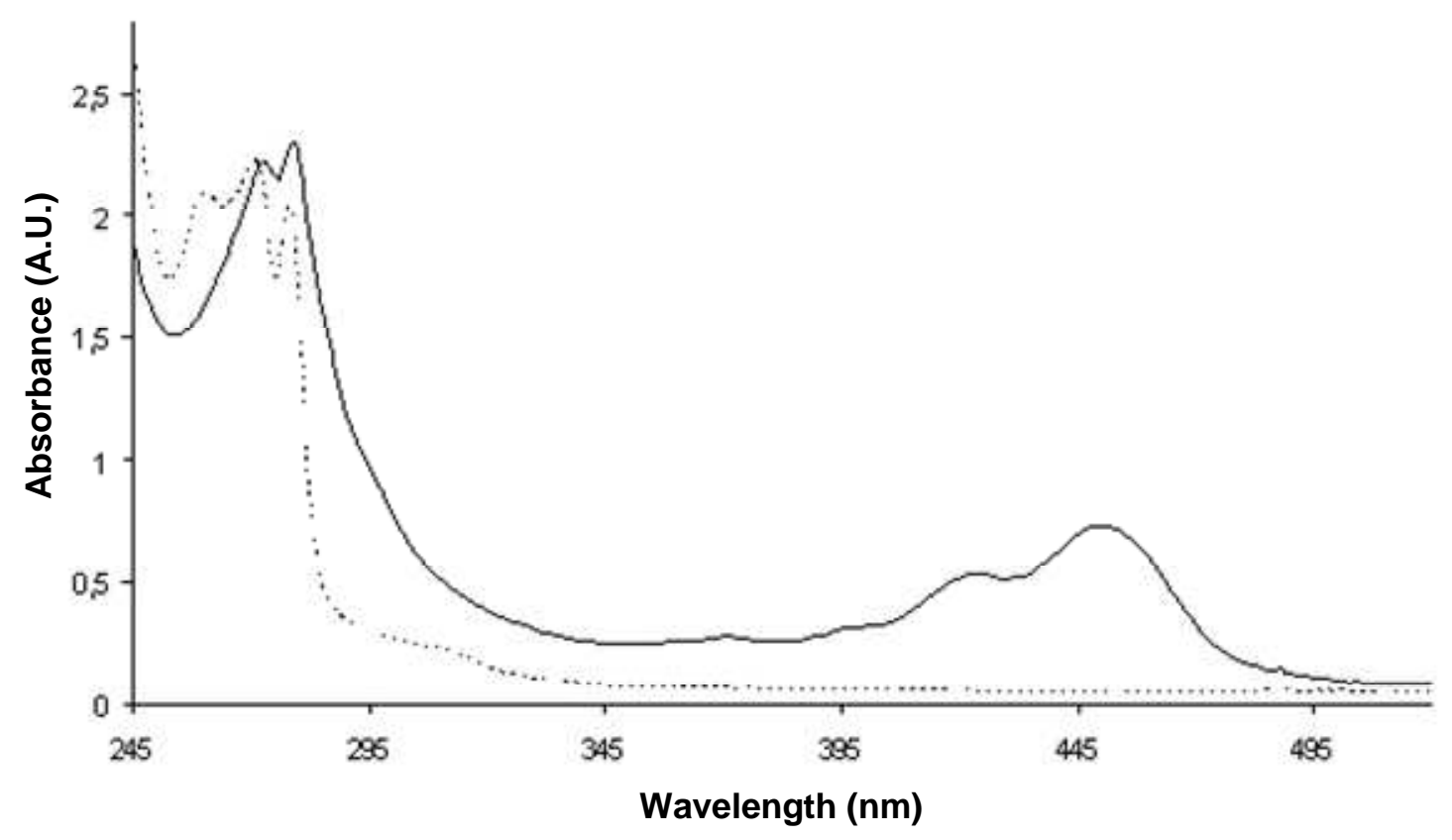

Figure 5. UV spectra of copolymer (4) prior to thermal curing (dotted line) and after $15 \mathrm{~min}$ of thermal curing at $170{ }^{\circ} \mathrm{C}$ (solid line). 
After heating to $170{ }^{\circ} \mathrm{C}$ for $15 \mathrm{~min}$, a new absorption band appeared in the spectrum as a broad signal centered at $470 \mathrm{~nm}$, while the band at $254 \mathrm{~nm}$ vanished. This was concomitant with a drastic color change from colorless to dark red, which is known to result from $\pi$ delocalization along the cross-linked diacetylenes network. ${ }^{68}$

These additional thermal properties are consistent with the block structure of copolymer (4), as depicted in Scheme 6.

\section{Thermo-oxidative stability}

Thermal stabilities of copolymer (1) and homopolymer (3) were investigated by thermogravimetric analysis (TGA). The thermal behavior of poly(1,10-triazolofluorodecaneco-methyleneether hexafluorobisphenol AF) copolymer (1) was established both under air (Figure 6.a) and under nitrogen atmosphere (Figure 6.b).

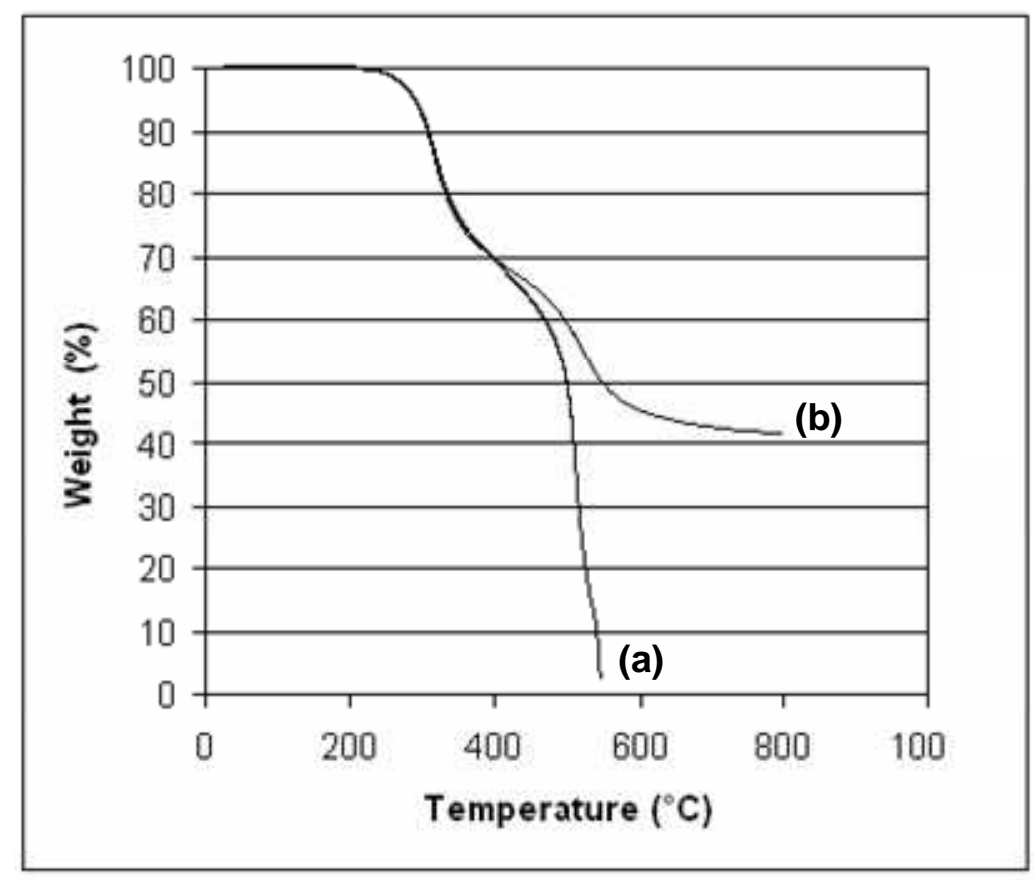

Figure 6. TGA thermograms of copolymer (1) at $20{ }^{\circ} \mathrm{C} \cdot \mathrm{min}^{-1}$ under air (a) and under Nitrogen atmosphere (b). 
Thermal gravimetric analysis of copolymer (1) obtained under air (Figure 6-a) indicated that these original copolymers had a good thermo-oxidative stability with a weight loss starting at around $270{ }^{\circ} \mathrm{C}$. Two stages were observed in the thermal decomposition. The first step from 300 to $473{ }^{\circ} \mathrm{C}$ corresponded to a 40 wt. \% loss and could be attributed to the loss of aliphatic segments due to the cleavage of the $\mathrm{CH}_{2}-\mathrm{N}$ bonds, which has been previously reported to occur at $360^{\circ} \mathrm{C}$, by Hans et al. ${ }^{69}$ and by Gaur et al. ${ }^{70}$ Above $473{ }^{\circ} \mathrm{C}$, the degradations of both aryl moities ${ }^{71}$ and of the triazole ring ${ }^{72}$ were observed, with a complete decomposition reached at $520{ }^{\circ} \mathrm{C}$.

The thermal degradation trace for copolymer (1) under nitrogen atmosphere was unchanged between 270 and $410{ }^{\circ} \mathrm{C}$ (Figure 6-b), confirming that the first stage of the degradation of the copolymers is only temperature related. However, from 550 up to $600{ }^{\circ} \mathrm{C}$, the decomposition was much slower and even reached a plateau above $650{ }^{\circ} \mathrm{C}$ up to $800{ }^{\circ} \mathrm{C}$, showing a high residue weight (higher than $40 \%$ ) at $800{ }^{\circ} \mathrm{C}$. Such a difference of degradation rates above 550 ${ }^{\circ} \mathrm{C}$ between air and nitrogen atmosphere has already been reported in the case of polytriazole resins by Xue et $a{ }^{72}$ who suggested that the second stage corresponds to a thermo-oxidative degradation. Under air, oxygen participates in the formation of chars at temperatures below $550{ }^{\circ} \mathrm{C}$, which quickly decompose with increasing temperature. No residue remained at 800 ${ }^{\circ} \mathrm{C}$ (Figure 6-a).

The TGA thermogram for homopolymer (experiment 3, Table 2) under oxygen atmosphere is presented in Figure 7. As expected, the thermal stability of the homopolymer was higher than that of copolymer (1), as justified by its aromatic backbone. A single weight loss was observed (10 wt. \% loss reached at about $550{ }^{\circ} \mathrm{C}$ ) and corresponded to the thermal full degradation of the polymeric chain. 


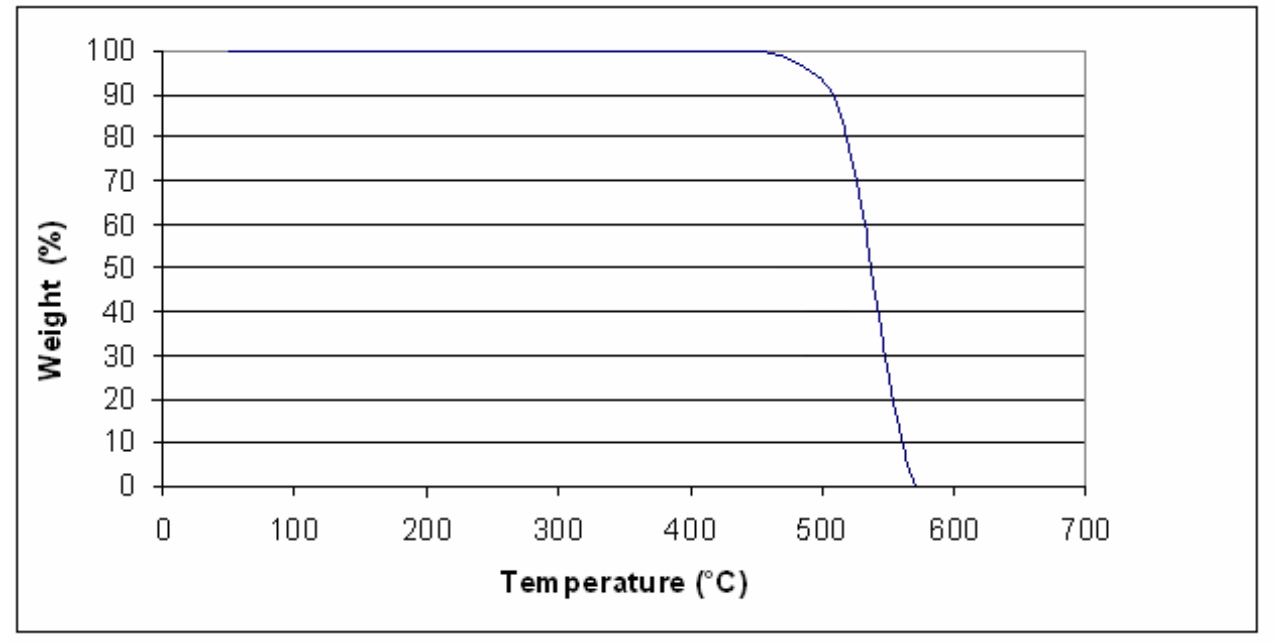

Figure 7. TGA thermogram of homopolymer (3) at $20{ }^{\circ} \mathrm{C} \cdot \mathrm{min}^{-1}$ under air.

The results of thermal analysis demonstrated that these original polymers exhibit high thermooxidative stabilities under air.

\section{Conclusions.}

Original fluorinated copolymers containing triazoles and based on oligo(tetrafluoroethylene) were synthesized by condensation via azide/alkyne "click" reaction between a telechelic aryl diyne and a fluorinated telechelic diazido compound. The latter was synthesized in two steps from the bis(ethylenation) of the $\alpha, \omega$-diiodo fluorinated telomers followed by a nucleophilic substitution of iodine atoms by sodium azide. This polycondensation was simple, clean, occurred in mild conditions and led to high yields.

However, under low oxygen amount and in the absence of copper II reductive agent, the homocoupling of terminal alkynes in polycondensates obtained by "Click" reaction occurred when the alkyne concentration was higher than that of azide. The presence of isolated diacetylenic units was demonstrated by the presence of a signal at $2264 \mathrm{~cm}^{-1}$ in the RAMAN spectra of the obtained copolymers. This side reaction enabled us to produce high molecular weight-copolymers (> 200,000 g/mol) via bridging central diacetylene units. 
Furthermore, in the presence of oxygen, 2,2'-bipyridine as the ligand and $\mathrm{Cu}(\mathrm{II})$ salt, the side reaction was turned into a competitive reaction leading to the synthesis of block copolymers. Such an original structure was confirmed by both DSC and UV-vis analyses. The corresponding DSC thermogram evidenced the presence of an exothermic peak close to 183 ${ }^{\circ} \mathrm{C}$, which was attributed to thermally activated cross-linking of diacetylenes. The polymerization of diacetylenes moieties was further confirmed by the presence of a broad absorption band at $470 \mathrm{~nm}$ in the UV-vis spectrum of the thermally cured copolymer.

Hence, thanks to the ability of the monomers to undergo either Hay coupling or "Click" reaction, a simple tune of the reaction conditions allowed us to obtain three drastically different copolymers from a same set of precursors. These new fluorinated polymers exhibit interesting thermal and thermo-oxidative stabilities by the presence of the triazole ring, which can withstand high thermal temperatures (up to $550{ }^{\circ} \mathrm{C}$ ) under air.

Acknowledgments. The authors thank DuPont Performance Elastomers company for a partially financing support of this study, Dr David Bourgogne (Inst. Charles. Gerhardt. Montpellier) for RAMAN spectroscopy analysis and Akzo Nobel company for providing free samples of di(4-tert-butylcyclohexyl)peroxydicarbonate.

Supporting Information Available. Raman spectrum of hexafluoro bisphenol AF dipropargylether, ${ }^{1} \mathrm{H},{ }^{19} \mathrm{~F}$ NMR, and infrared spectra of $\mathrm{N}_{3} \mathrm{C}_{2} \mathrm{H}_{4} \mathrm{C}_{6} \mathrm{~F}_{12} \mathrm{C}_{2} \mathrm{H}_{4} \mathrm{~N}_{3},{ }^{1} \mathrm{H},{ }^{13} \mathrm{C}$ NMR spectra and SEC chromatogram of homopolymer (3), and ${ }^{13} \mathrm{C}$ NMR and infrared spectra of copolymer (4) are provided. This material is available free of charge via internet at http://pubs.acs.org 


\section{References and Notes}

(1) Scheirs, J. Modern Fluoropolymers, Wiley: New York 1997.

(2) Hougham, G., Cassidy, P.E., Johns, K., Davidson, T. Fluoropolymers, Vol. 2:

Properties ; Kluvert: New York, 1999.

(3) Ameduri, B., Boutevin, B. Well-Architectured Fluoropolymers: Synthesis, Properties and Applications; Elsevier: Amsterdam, 2004.

(4) D’Alelio, A. U.S. Pat. No. 5,562,231 1971 Assigned to The United States of America as represented by the Secretary of the Air (Washington, D.C.).

(5) Picklesimer L.G., U.S. Pat. No. 4,226,800, 1980, Assigned to The United States of America as represented by the Secretary of the Air (Washington, D.C.).

(6) Wu et al. ACS Symposium 1990 Series 417, Washington D.C.

(7) Sillion, B., Rabillaud, G., "Hetrocycle polymers with high glass transition temperatures" in Ebdon J. R., Eastmond G.C. (Ed) High Tg Heterocyclic polymers, 1995 Chapter 7, p236-289, Blackie Publishers, Glasgow (UK).

(8) a. Dirlikov, S., Feng, Y., Proceeding of the ACS. Div. Polym. Mat. Sci. Eng., 1988, 59, 990-991; b. Feng, Y., Dirlikov, S. K., Proceeding of the ACS. Div.Polym. Mater. Sci. Eng. 1989, 60, 618-619; c. Feng, Y., Dirlikov, S. K., Proceeding of the ACS. Div. Polym. Mater. Sci. Eng. 1989, 61, 835-836; d. Dirlikov, S. K., Feng, Y., $3^{\text {rd }}$ International SAMPE Electronics Conference 1989, 3, 169-172; e. Dirlikov, S. K., Feng, Y., Proc. Polym. Mat. Sci. Eng. 1990, 62, 603-604; f. Dirlikov, S.K., Feng, Y. Polymer Preprints (American Chemical Society, Div. Polym. Chem.) 1990, 31, 322-323; g. Chen, Z., Wang, D., Dirlikov, S.K., Polym. Mat. Sci. Eng. 1993, 69, 388-389.

(9) a) Goldschalx, J.P., Inbasekaran, M. N., Bartos, B.R., Schek, D.M., Laman, S.A., Int. SAMPE Tech. Conf. 1990, 22, 163; b. Douglas, WE., Overend, A.S., Eur. Polym. J. 1991, 27, 1279-1285. 
(10) Richer, S., Alamercery, S., Paisse O., Raffin, G., Sanglar, C., Waton, H., GrenierLoustalot, M.F., Polymers \& Polymer Composites 2001, 9(2), 103-120.

(11) a. Glaser, C., Ber. Ditsch. Chem. Ges. 1869, 2, 422-424; b. Glaser, C., Ann. Chem. Pharm. 1870, 154, 137-171.

(12) a. Hay, AS., J. Org. Chem. 1960, 25, 1275-1280; b. Hay, AS., J. Org. Chem. 1962, $27,3320-3322$.

(13) Raphael, Acetylene Compounds in Organic Synthesis 1965, 127, Academic Press, New-York.

(14) Siemsen, P., Levingston, R.C., Diederich, F. Angew. Chem. Int. Ed. 2000, 39, 26322657.

(15) Carpick, R.W., Sasaki, D.Y., Marcus, M.S., Eriksson, M.A., Burns, A.R. J. Phys. Condens. Matter. 2004, 16, R679-R697.

(16) a) Kolb, HC., Finn, MG., Sharpless, KB., Angew. Chem. Int Ed. 2001, 40, 2004.; b) Rostovtsev, L.G., Green, L.G., Fokin, V.V., Sharpless, KB., Angew. Chem. Int. Ed. 2002, $41,2596-2601$.

(17) Bock, V.D., Hiemstra, H., Maarseveen, J.H.V., Eur. J. Org. Chem. 2006, 2006, 5155.

(18) Punna, S., Kuzelka, J., Wang, Q., Finn, M.G. Angew. Chem. Int. Ed. 2005, 44, $2215-$ 2221.

(19) Himo, F., Lovell,T., Hilgraf, R., Rostovtsev,V.V., Noodleman, L., Sharpless, K.B., Fokin, V.V. J. Am. Chem. Soc. 2005, 127, 210-216.

(20) Meng, J-C, Fokin,V.V., Finn, M.G. Tetrahedron Letters 2005, 46, 4543-4546.

(21) Lewis, W.G., Magallon, F.G., Fokin, V.V., Finn, M.G. J. Am. Chem. Soc. 2004, 126, 9152-9156. 
(22) Golas, P.L., Tsarevsky, N.V., Sumerlin, B.S., Matyjaszewski, K., Macromolecules 2006, 39, 6451-6456.

(23) Jang, H., Fafarman, A., Holub, J.M., Kirshenbaum, K. Org. Lett. 2005, 7, 1951-1954.

(24) Bodine, K.D., Gin, D.Y., Gin, M.S. J. Am. Chem. Soc. 2004, 126, 1638-1639.

(25) Bock, V.D., Hiemstra, H., Van Maarseveen, J.H. Eur. J. Org. Chem. 2005, 51-68.

(26) Wang, ZX, Qin HL., Chem Commun. 2003, 19, 2450-2455.

(27) Mamat, C.; Ramenda, T.; Wuest, F.R. Mini-Reviews in Organic Chemistry, 2009, 6, 21-26.

(28) Badjic, JD., Balzani, V., Credi, A., Lowe, JN., Silvi, S. Stoddart, JF. Chem. Eur. J. 2004, 10, 1926-1931.

(29) Zhang, X.; Lian, X.; Liu, L.; Zhang, J.; Zhao, H. Macromolecules 2008, 41, 78637868.

(30) Haensch, C.; Chiper, M.; Ulbricht, C.; Winter, A.; Hoeppener, S.; Schubert, U.S. Langmuir, 2008, 24, 12981.

(31) Scheel AJ, Komber, H., Viot, BI., Macromol Rapid Commun 2004, 25, 1175-1182.

(32) Sumerlin, B.S., Vogt, A.P. Macromolecules 2010, 43, 1-13.

(33) Binder, W.H., Sachsenhofer, R., Macromol Rapid Commun 2008, 29, 952-961.

(34) Wu, P., Feldman, AK., Nugent, AK., Hawker, CJ., Scheel, A., Voit, B., Angew. Chem. Int. Ed. 2004, 43, 3928-3934.

(35) Van Steenis, DJVC., David, ORP., Van Strijdonck, GPF., Van Maarseveen, JH, Reek, JNH., Chem. Commun. 2005, 34, 4333-4335.

(36) Helms, B., Mynar, JL., Hawker, CJ., Fréchet, JMJ. J. Am. Chem. Soc. 2005, 126, $15020-15025$.

(37) Parrish,B., Breiteinkamp, RB., Emrick, T. J. Am. Chem. Soc. 2005, 127, 7404-7408. 
(38) Carroll, JB., Jordan, BJ., Xu, H., Herdogan, B., Lee, L., Cheng, L., Org. Lett. 2005,7, 2551-2558.

(39) Fournier, D., Hoogenboom, R., Schubert, US., Chem. Soc. Rev. 2007, 36, 1369.

(40) Diaz, DD., Punna, S., Holzer, P., Mc Pherson, AK., Fokin, VV., J. Polym. Sci.Part A. Polym. Chem. 2004, 42, 4392-4398.

(41) Opsteen, JA., Van Hest, JCM., Chem Commun. 2005, 1, 57-60.

(42) Ossipov, DA., Hilborn, J., Macromolecules 2006, 39, 1709-1722.

(43) Aucagne, V., Leigh, D.A., Org. Lett. 2005, 8, 4505-4509.

(44) Steenis, D.J.V.C., David, O.R.P., Strijdonck, G.P.F., Maarseveen, J.H., Reek, J.N.H. Chem. Commun. 2005, 4333-4336.

(45) Malkoch, M., Vestberg, R., Gupta, N., Mespouille, L., Dubois, P., Mason, A.F., Hedrick, J.L., Liao, Q., Frank, C.W., Kingsbury, K., Hawker, C.J., Chem. Commun. 2006, 2774-2777.

(46) Diaz, D.D., Rajapogopal, K., Strable, E., Schneider, J., Finn, M.G., J. Am. Chem. Soc. 2006, 128, 6056-6071.

(47) Yuanqin, Z., Yangen, H., Wei-Dong, M, Hongqi, Li., Feng-Ling, Q. Polymer 2006, 47, 6272-6283.

(48) Baut, N.L., Diaz, D.D., Punna, S., Finn, M.G., Brown, H.R., Polymer 2007, 48, 239243.

(49) Liu, Y., Diaz, D.D., Accurso, A., Sharpless, K.B., Fokin, V.V., Finn, M.G., J. Polym. Sci., Part A: Polym. Chem. 2007, 45, 5182-5188.

(50) Qin, A., Jim, C.K.W., Lu, W., Lam, J.W.Y., Haussler, M., Dong. Y., Sung, H.H.Y., Williams, I.D., Wong, G.K.L., Tang, B.Z., Macromolecules 2007, 40, 2308-2322.

(51) Binauld, S., Boisson, F., Hamaide, T., Pascault, J.P., Drockenmuller, E., Fleury, E. J. Polym. Sci. Part A: Polym Chem. 2008, 46,5506-5517. 
(52) a. Cummins, D., Duxbury, C.J., Quaedflieg, P.J.L.M., Magusin, P.C.M.M., Koning, C.E., Heise, A., Soft Matter 2009, 5, 804-811; b. Duxbury, C.J., Cummins, D., Heise, A., J. Polym. Sci., Part A: Polym. Chem. 2009, 47, 3795-3802.

(53) (a) Hay, AS. Polymer Letters 1970, 8, 97-101. (b) Hay, AS. US Patent, 3, 594, 175, 1971. (c) Hay, AS., Bolon, DA., Leimer, KR., Clark, RF. J. Polym. Sci. Polym. Lett. 1970, 8, 97-102.

(54) Patterson, M.L., Weaver, M.J. J. Phys. Chem. 1985, 89, 5051-5057.

(55) Manseri, A., Ameduri, B., Boutevin, B., Kotora, M., Hajek, M., Caporiccio, G. J. Fluorine. Chem., 1995, 73, 151-158.

(56) Malik, A., Tzeng, D., Tcheng, P., Baum, K. J. Org. Chem., 1991, 56, 3043-3044.

(57) a. Lutz, JF., Borner, HG., Weichenhan, K. Macromol. Rapid. Commun., 2005, 26, 514-518; b. Lutz, JF. Angew. Chem. Int. Ed. 2007, 46, 1018-1025.

(58) Mayot, E., Gérardin-Charbonnier, C., Selve, C. J. Fluorine Chem., 2005, 126, 715720.

(59) Pergolese, B., Muniz-Miranda, M., Bigotto, A. Vibrational Spectroscopy 2008, 48, 202-205.

(60) Gan, H., Liu, H., Li, Y., Zhao, Q., Li, Y., Wang, S., Jiu, T.,Wang, N., He, X., Yu, D., Zhu, D. J. Am. Chem. Soc. 2005, 127, 12452-12453.

(61) Jahnke, E., Lieberwirth, I., Severin, N., Rabe, J.P., Frauenrath, H. Angew. Chem. 2006, 118, 5510; Angew. Chem. Int. Ed. 2006, 45, 5383-5388.

(62) (a) Karangu, N.T., Rezac, M.E., Beckham, H.W. Chem. Mater. 1998, 10, 567-572. (b) Karangu, N.T., Girardeau, T.E., Sturgill, G.K., Rezac, M.E., Beckham, H.W. Polymer 2001, 42, 2031-2037.

(63) Badarau, C., Wang, Z.Y. Macromolecules 2004, 37, 147-153.

(64) Rezac, M.E., Sorensen, E.T., Beckham, H.W. J. Membr. Sci. 1997, 136, 249-252. 
(65) Miller, T.M., Knowck, E.W., Baird, T., Hale, A. Chem. Mat. 1994, 6, 1569-1572.

(66) Beckham, H.W., Rubner, M.F. Macromolecules 1993, 26, 5192-5197.

(67) Wiley, R.H., Smith, N.R., Jonhson, D. M., Moffat, J. J. Am. Chem. Soc., 1954, 76, 4933-4938.

(68) Bloor, D., Chance, R.R. 1985 Polydiacetylenes: Synthesis, Structure, and Electronic Properties (Dordrecht: Martinus Nijhoff)

(69) Hans, B., Ralph, D., Sitki, A. J. Am. Chem. Soc. 1983, 105, 7681-7685.

(70) Gaur, B., Lochab, B., Choudhary, V., Varna, I.K. J. Therm. Anal. Calorim. 2003, 71, 467-479.

(71) Ghassemi, H., Mc Grath, J.E., Zawodzinski, T.A. Polymer 2006, 47, 4132-4139.

(72) Xue, L., Wan, L., Hu, Y., Shen, X., Huang, F. Thermochimica Acta 2006, 448, $147-$ 153. 
SYNOPSIS TOC

Original Fluorinated Copolymers Achieved by both Azide/alkyne "Click" Reaction and Hay Coupling from Tetrafluoroethylene Telomers

Aurélien Soules, Bruno Ameduri,

Bernard Boutevin, Gerard Calleja

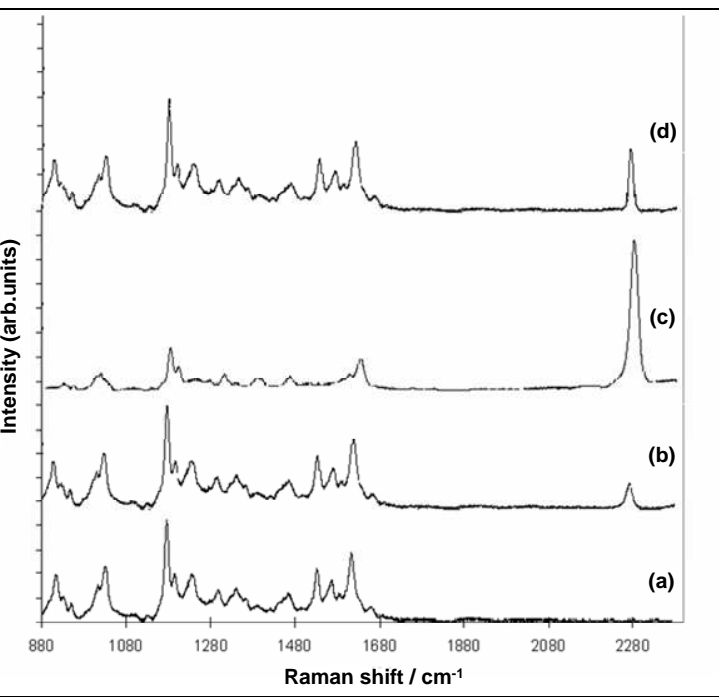




\section{Table Captions}

Table 1. Experimental conditions (variation of the temperature $(\mathrm{T})$, the reaction time $(\mathrm{t})$, and the $\left[\mathrm{NaN}_{3}\right]_{0} /\left[\mathrm{IC}_{2} \mathrm{H}_{4} \mathrm{C}_{6} \mathrm{~F}_{12} \mathrm{C}_{2} \mathrm{H}_{4} \mathrm{I}\right]_{0}$ initial molar ratio and yields of telechelic $\mathrm{N}_{3}-\mathrm{C}_{2} \mathrm{H}_{4}-\mathrm{C}_{6} \mathrm{~F}_{12}-$ $\mathrm{C}_{2} \mathrm{H}_{4}-\mathrm{N}_{3}$ diazido (B).

Table 2. Experimental conditions, yields, molecular weights, polydispersity indices (PDIs) and intrinsic viscosities of the polymers synthesized from the condensation of 1,10-diazido$1 \mathrm{H}, 1 \mathrm{H}, 2 \mathrm{H}, 2 \mathrm{H}, 9 \mathrm{H}, 9 \mathrm{H}, 10 \mathrm{H}, 10 \mathrm{H}$-perfluorodecane $(\mathbf{B})$ with $\alpha, \omega$-dipropargyl ether bisphenol AF (A). 


\begin{tabular}{|c|c|c|c|c|}
\hline Entry & $\mathrm{T}\left({ }^{\circ} \mathrm{C}\right)$ & $\mathrm{t}(\mathrm{hr})$ & {$\left[\mathrm{NaN}_{3}\right]_{0} /\left[\mathrm{IC}_{2} \mathrm{H}_{4} \mathrm{C}_{6} \mathrm{~F}_{12} \mathrm{C}_{2} \mathrm{H}_{4} \mathrm{I}\right]_{0}$} & $\begin{array}{c}\text { Yield } \\
(\%)\end{array}$ \\
\hline 1 & $\mathrm{RT}$ & 96 & 3 & 30 \\
\hline 2 & $\mathrm{RT}$ & 96 & 6 & 40 \\
\hline 3 & 50 & 48 & 3 & $>95$ \\
\hline
\end{tabular}

Table 1. Experimental conditions (variation of the temperature $(\mathrm{T})$, the reaction time $(\mathrm{t})$, and the $\left[\mathrm{NaN}_{3}\right]_{0} /\left[\mathrm{IC}_{2} \mathrm{H}_{4} \mathrm{C}_{6} \mathrm{~F}_{12} \mathrm{C}_{2} \mathrm{H}_{4} \mathrm{I}\right]_{0}$ initial molar ratio and yields of telechelic $\mathrm{N}_{3}-\mathrm{C}_{2} \mathrm{H}_{4}-\mathrm{C}_{6} \mathrm{~F}_{12}-$ $\mathrm{C}_{2} \mathrm{H}_{4}-\mathrm{N}_{3}$ diazido (B). 


\begin{tabular}{|c|c|c|c|c|c|c|c|}
\hline Exp. & $\begin{array}{c}\mathrm{A} / \mathrm{B} / \mathrm{CuBr} / \\
\text { bpy } \\
(\mathrm{mmol})^{\mathrm{a}}\end{array}$ & $r$ & Atmosphere & $\begin{array}{c}\text { Yield } \\
(\%)\end{array}$ & $\begin{array}{c}\mathrm{Mn}^{\mathrm{b}} \\
(\mathrm{g} / \mathrm{mol})\end{array}$ & PDI & $\begin{array}{c}{\left[\eta^{35^{\circ} \mathrm{C}}\right]^{\mathrm{c}}} \\
\left(\mathrm{dL} . \mathrm{g}^{-1}\right)\end{array}$ \\
\hline 1 & $4.94 / 5.10 / 0.40 / 0.80$ & $0.97^{\mathrm{d}}$ & $\mathrm{N}_{2} / \mathrm{O}_{2}$ Traces & 60 & 37,000 & 1.8 & 0.4 \\
\hline 2 & $1.21 / 1.20 / 0.40 / 0.80$ & $0.99^{\mathrm{e}}$ & $\mathrm{N}_{2} / \mathrm{O}_{2}$ Traces & 65 & $\begin{array}{c}50,000 \text { to } \\
>200,000\end{array}$ & 5.3 & 0.6 \\
\hline 3 & $1.20 / 0.00 / 0.40 / 0.80$ & - & $\mathrm{N}_{2} / \mathrm{O}_{2}$ Traces & 43 & $\begin{array}{c}5000 \text { to } \\
40,000\end{array}$ & 1.8 & - \\
\hline 4 & $1.21 / 1.20 / 0.40 / 0.80$ & $0.99^{\mathrm{e}}$ & $\mathrm{O}_{2}$ & 60 & 60,000 & 1.8 & 0.4 \\
\hline
\end{tabular}

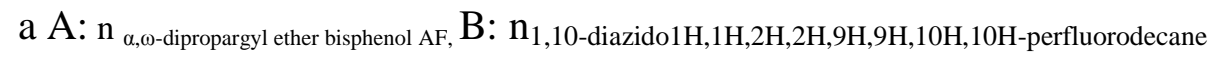
b Mn assessed by SEC (Polystyrene standards)
c Intrinsic viscosity assessed in acetone at $35^{\circ} \mathrm{C}$
$\mathrm{d} r=\mathrm{A} / \mathrm{B}$
$\mathrm{e} r=\mathrm{B} / \mathrm{A}$

Table 2. Experimental conditions, yields, molecular weights, polydispersity indices (PDIs) and intrinsic viscosities of the polymers synthesized from the condensation of 1,10-diazido$1 \mathrm{H}, 1 \mathrm{H}, 2 \mathrm{H}, 2 \mathrm{H}, 9 \mathrm{H}, 9 \mathrm{H}, 10 \mathrm{H}, 10 \mathrm{H}$-perfluorodecane (B) with $\alpha, \omega$-dipropargyl ether bisphenol AF (A). 